\title{
ANÁLISE DO RECURSO CONTRA O PODER CONCLUSIVO DAS
} COMISSÕES

\author{
Suzana Cristina Leite ${ }^{1}$
}

Resumo: Estudo dos recursos ao poder conclusivo das comissões da Câmara dos Deputados. Faz uma análise de dados do seu cabimento, de suas razões, sua ocorrência e a influência do Executivo. Para tanto, sistematiza as informações através da identificação e estudo dos dados que abrangem a $52^{\mathrm{a}}$ Legislatura. Aborda os mecanismos regimentais pertinentes, além dos outros fatores intervenientes.

Palavras-chave: Poder Legislativo. Senado Federal. Câmara dos Deputados. Poder Conclusivo. Poder pleno. Comissões. Recurso.

\begin{abstract}
This paper studies the appeals to the conclusive power of the Brazilian House of Representatives' committees. It analyzes the data related to its acceptance, motives, occurrences and the influence of the Executive Branch. In order to achieve that goal, it organizes the information through the identification and study of the data encompassing the $52^{\text {nd }}$ Legislature. It takes into consideration the pertinent regulatory mechanisms as well as other contributing factors.
\end{abstract}

Keywords: Legislative Branch. Senate. House of Representatives. Conclusive power. Full power. Committees. Appeal.

\section{Introdução}

O presente trabalho "Recurso contra o Poder Conclusivo das Comissões - uma análise" é fruto de uma pesquisa de processo legislativo da Câmara dos Deputados, que buscou, por meio da identificação, sistematização e avaliação destes recursos apresentados na Câmara dos Deputados - 52 $2^{\mathrm{a}}$ Legislatura, identificar e estudar as diversas influências que modificam a tramitação legislativa das proposições principais. O objetivo é analisar o recurso, sua incidência e legitimidade, além de buscar identificar o poder de agenda do Executivo, exercido por meio de

\footnotetext{
${ }^{1}$ Advogada OAB/DF, com especialização em Direito Tributário pela Faculdade Projeção/Fortium, e especialização em Processo Legislativo pelo CEFOR - Câmara dos Deputados, e graduação em Ciências Jurídicas pelo Instituto de Educação Superior de Brasília - IESB. Servidora Pública da Câmara dos Deputados, desde 1989.
} 
sua competência co-legislativa e pela influência sobre a atuação parlamentar.

A escolha de uma legislatura se deu em respeito ao Princípio da Unidade da Legislatura, um dos princípios do processo legislativo que abordaremos ao longo do trabalho. Isto porque assim poderemos avaliar, de forma fechada, o comportamento deste instituto e observar os objetivos estratégicos dos parlamentares nestas ações.

Há uma tendência mundial de fortalecimento e especialização dos trabalhos de comissão. No Brasil, o sistema de comissões nas Casas Legislativas foi inovado com o disposto no art. 58, § $2^{\circ}$ da Constituição Federal de 1988, que deu poder pleno a essas comissões temáticas para trabalhar de forma conclusiva na produção legislativa federal. Por se tratar de um instituto novo para a nossa realidade atrai atenção e merece estudos para sua avaliação.

Esse novo poder criou expectativas quanto à celeridade do processo, à especialização e ao aprofundamento das discussões, despertando interesse dos estudiosos em conhecer a qualidade e a quantidade das normas produzidas neste novo desempenho das comissões, agora órgão de apreciação legislativa dos projetos para a produção de leis ordinárias. Muitos trabalhos científicos vêm sendo desenvolvidos no sentido de conhecer o desempenho deste instituto pós 1988. Alguns estudos questionam as deficiências de ordem normativa e organizacional e se realmente essas comissões estão se fortalecendo ao longo destes 21 anos de existência, quando se dispensou a apreciação plenária.

No entanto, uma proposição irá à apreciação plenária dependendo da aprovação de recurso constitucional, art. 58, salvo exceções. Por se tratar de tema novo na realidade brasileira, pouco ou quase nada há de avaliações sobre os resultados dos recursos ao Plenário, apresentados por um décimo dos parlamentares, contra o poder conclusivo das comissões. Para a análise de dados dos recursos na $52^{\text {a }}$ Legislatura e uma avaliação na interferência do Executivo sobre este instituto uma pesquisa foi feita nas fichas de "Consulta Tramitação das Proposições" da página eletrônica da Câmara dos Deputados. Tal levantamento ajudou na compreensão da tramitação e trouxe resultados que serviram como uma avaliação dos recursos apresentados, a forma como regimentalmente se permite a sua interposição, como desenrolam, de modo a identificar a presença do Executivo na produção legislativa. Pode ainda vir a servir de reflexão para possíveis alterações regimentais.

\section{A Assembleia Nacional Constituinte e a aprovação do dispositivo}

O dispositivo constitucional que assegura o Poder Conclusivo das Comissões e o recurso de um décimo de seus membros para encaminhamento do projeto ao Plenário, art. 58, § $2^{\circ}$, I, da Constituição Federal, foi inserido no texto constitucional pela Assembleia Nacional Constituinte, em 18 de março de 1988.

A primeira ocorrência do Poder Conclusivo nos trabalhos da Constituinte foi a Emenda 
2P00107-6, de autoria do Constituinte Henrique Córdova, que, entre outros assuntos, já apresentava a disposição praticamente pronta, in verbis:

Emenda: 2P00107-6

Dêem-se aos parágrafos $1^{\circ}$ e $2^{\circ}$, do Artigo 72, do Projeto de Constituição, a redação que segue e mantenham-se os Artigos $3^{\circ}$ e $4^{\circ}$

Art. 72

$\S 2^{\circ}$ Às comissões, em razão da matéria de sua competência, cabe:

I - discutir e votar projetos de lei que dispensam, na forma do regimento, a competência do Plenário, salvo com recurso de um décimo dos membros da Casa.

(grifo nosso)

O autor da proposta argumenta que seu trabalho está baseado em três ordens distintas de ideias: restauração das prerrogativas do Poder Legislativo; necessidade de garantir maior agilidade na função legislativa; e maior eficiência na função fiscalizadora e de criar mecanismos de participação do povo na elaboração das leis, nas decisões do poder. Quando da defesa de sua emenda, o autor apresenta:

Para a materialização dessas concepções, entendeu-se que havia necessidade de se descentralizar as atividades do Poder Legislativo. Esta a razão pela qual, ao contrário de textos constitucionais anteriores, foi dado um tratamento mais minucioso à matéria relativa às Comissões Permanentes, tanto na Câmara dos Deputados como do Senado Federal e do Congresso Nacional (Córdova, 1987, p. 114).

O fortalecimento das comissões e a desobstrução do Plenário foi tema amplamente debatido e apoiado pela Subcomissão do Poder Legislativo e pela Comissão da Organização dos Poderes e Sistema de Governo. Neste espírito de defesa da valorização dos trabalhos em comissão, houve muitas ideias e manifestações parlamentares. Destacamos o fato de o Constituinte Victor Faccioni ter proposto a redução do número de sessões do Plenário e estabelecido os dias de funcionamento das comissões. Ele teve como objetivo chamar a atenção da Casa, da imprensa e da opinião pública sobre essa nova tarefa das comissões. (DANC Suplemento, 1987, p. 28)

As notas taquigráficas e a Ata da $8^{\circ}$ reunião ordinária dessa Subcomissão do Poder Legislativo demonstram a intenção de se devolverem as prerrogativas ao Poder Legislativo. O Constituinte José Jorge, relator, em 12 de maio de 1987, quando das explicações do relatório do anteprojeto, argumenta:

Tão importante quanto devolver as prerrogativas ao Poder Legislativo - antigo anseio de sucessivas gerações de parlamentares brasileiros, inconformados com a hipertrofia do Executivo - é dotar o Congresso Nacional de meios para exercê-las em sua plenitude, com a eficiência que se requer de um parlamentar ágil e moderno.

Um parlamento que orbita em torno apenas de seu Plenário está condenado à lentidão, à inércia e à ineficiência, perdido no tempo e no rumo da estagnação. A evolução natural desta Instituição impõe que parte das atribuições hoje, exclusivas do Plenário, seja distribuída a outros colegiados, menores e mais ágeis, além de serem em maior número. A solução - há muito conhecida por quantos parlamentares passaram por estas duas Casas - é o fortalecimento das comissões técnicas, que devem ter novas funções, novas condições e principalmente novos poderes. 
Assim, as Comissões Técnicas da Câmara e do Senado, que nem são citadas na atual Constituição, agora passam a ter um artigo específico que lhes confere uma série de atribuições, as quais certamente farão com que tenham um papel fundamental no novo Congresso que se pretende construir.

É inquietante a realidade atual que exibe, tramitando por longo período de tempo, cerca de dez mil projetos, cuja afluência ao Plenário sobrecarrega-lhe os trabalhos, tornandose tarefa difícil, se não inviável, a sua tempestiva apreciação. A alternativa proposta visa desobstruir os trabalhos do Plenário, imprimindo maior racionalidade e agilização do processo legislativo, da Comissão, e, por via de conseqüência, do Poder Legislativo como um todo. Entretanto, mediante solicitação de um décimo dos parlamentares de cada Casa Legislativa, poderá o Plenário avocar a si a discussão e deliberação sobre o projeto.

Portanto, haverá sempre uma possibilidade de se recorrer ao Plenário. (Jorge, 1987, p. 151-152) (grifo nosso)

Diferentemente do que argumentou o autor, as comissões são citadas nas várias Constituições brasileiras desde a primeira, do Império, de 1824. Porém, recente foi o sentimento de fortalecimento do Poder Legislativo e a criação do poder conclusivo das comissões apresentou-se como inevitável. A expectativa era de que a apreciação em comissão teria análise em muitos fóruns de debates, mais ágeis e especializados. Além disso, a desobstrução do Plenário seria útil à apreciação de temas mais abrangentes e relevantes.

Em Plenário, o dispositivo foi apreciado e aprovado em fusão - Substitutivo - Emenda 2P02040, dos senhores Constituintes Henrique Córdova e Fernando Lyra. Nesta ocasião, Pimenta da Veiga vê a aprovação dessa emenda, que dá nova estrutura aos trabalhos das comissões técnicas, como um notável avanço e modernidade, considerando que o Plenário ficará resguardado para exame dos temas com "real importância", mas reconhecendo como “indispensável” o recurso ao Plenário (DANC, 1988, p. 8.621)

Dessa forma, a Assembleia Nacional Constituinte, sob a presidência de Ulysses Guimarães, em 18 de março de 1988, aprovou definitivamente a delegação plenária às comissões técnicas para tratar definitivamente sobre projetos de lei, na forma do regimento, e salvo recurso ao Plenário - art. 58, § 2º I, da Constituição Federal.

Em relação ao recurso, o relator citado apresenta-o com a seguinte argumentação: "mediante solicitação de um décimo dos parlamentares de cada Casa Legislativa, poderá o Plenário avocar a si a discussão e a deliberação sobre o projeto." Nesta ocasião, apenas argumenta que o Plenário chamará para si esta solicitação, porém o "poderá" soa como uma "alternativa" a ser definida pelo Plenário.

\subsection{O juízo prévio de apreciação do recurso ao poder conclusivo no Plenário}

O juízo prévio de apreciação do recurso não foi determinado pela Constituição Federal. A Carta Magna, art. 58, § $2^{\circ}$, I , no entanto, dispensa a apreciação plenária da proposição na forma do regimento interno, salvo recurso. Atualmente, o dispositivo está regulamentado nos 
regimentos internos de cada Casa do Legislativo.

Há autores que entendem que esse juízo prévio do Plenário, quanto à aprovação dos recursos, compromete o objetivo constitucional de dar uma garantia às minorias. Nesse contexto, Luciana Pacheco questiona a constitucionalidade do comando regimental na Câmara dos Deputados que prevê o provimento do recurso por decisão plenária. Manifesta-se nos seguintes termos:

A constitucionalidade do procedimento regimental, embora ainda não questionada formalmente, é duvidosa. Afinal, nos termos do art. 58, § 2º I, da Constituição Federal, o direito de que o Plenário delibere sobre matéria originalmente apreciada em caráter conclusivo pelas comissões constitui garantia assegurada às minorias (os dez por cento do total de membros da Casa). E o que o Regimento acabou fazendo, de fato, foi transferir esse direito para a maioria - o Plenário - pondo em suas mãos um juízo prévio sobre a conveniência, ou não, de a matéria votada pelas comissões ser levada à sua apreciação (Pacheco, 2002, p. 116).

Por sua vez, Vieira lembra que este conceito de direito das minorias está alinhado com a doutrina italiana. Pelo fato de exigir-se, via regimento interno, a aprovação plenária, criou-se uma reserva de Plenário, que o autor identificou como um hibridismo com o sistema espanhol. E, em suas palavras, apresenta:

O Regimento Interno da Câmara dos Deputados, no entanto, desnaturou esse direito das representações minoritárias da Casa ao exigir que o recurso apresentado por um décimo dos membros da Casa seja aceito pela maioria do Plenário, numa decisão preliminar de provimento, sem o que a proposição não será considerada pela totalidade da Casa (art. $132, \S 2^{\circ}$ ). Dessa forma, criou o regulamento interno da Câmara, um hibridismo com o sistema espanhol, que reserva ao Plenário a decisão sobre chamar para si uma matéria examinada pelas Comissões com competência legislativa plena (Vieira, 2005, p.67)

Até então, entende-se que o regimento interno apenas está regulamentando um comando constitucional, e, portanto, juridicamente está em consonância com a norma maior, a Carta Magna.

A Constituição Federal de 1988 possibilitou a um décimo de parlamentares a apresentação do recurso contra o poder conclusivo nas comissões. Assim, cada regimento interno de cada uma das Casas Legislativas - Câmara dos Deputados e Senado Federal regulamentou o recurso de forma independente, e, por conseguinte, diversa.

\section{Apresentação e análise dos dados apurados na 52 ${ }^{\text {a }}$ Legislatura na Câmara dos Deputados}

$\mathrm{Na}$ primeira análise dos dados, identificamos recursos de toda natureza indexados juntamente, no total de 315 proposições, no período de 2003-2006, em que estão juntos vários tipos de recursos ao Plenário: contra devolução de projetos, contra despachos e requerimentos entre outras decisões da presidência, inclusive recursos contra decisão da presidência por não concessão de palavra, questões de ordem, recursos a pareceres terminativos, e, além desses, 
contra o poder conclusivo das comissões, objeto de nossa análise.

Esses recursos têm numeração única por legislatura, iniciando-se na primeira Sessão Legislativa o número 01 que seguirá até o último documento do gênero apresentado na Legislatura, sempre acompanhado do respectivo ano de apresentação. Apresentam-se da seguinte forma exemplificativa: REC 315/2006.

Na pesquisa, junto à Secretaria-Geral da Mesa sobre os recursos ao poder conclusivo apresentados no período da $52^{\mathrm{a}}$ Legislatura, constatamos que não há uniformização de termos nas suas ementas, ou seja, a informação apresenta-se de várias formas. Os recursos identificamse ora contra "parecer" conclusivo, "apreciação" conclusiva, ou apenas, solicita apreciação pelo Plenário. Portanto, para que não houvesse perda de informação ao longo da coleta, não houve alternativa outra além da busca, um a um, dos recursos estudados neste trabalho. E, por conseguinte, a pesquisa das proposições às quais eles se referiam, já que apenas assim poderíamos visualizar o trajeto e o seu resultado.

Neste contexto, separamos a análise por fundamento regimental para melhor visualização das ocorrências. Posteriormente, uma análise mais detalhada dos subconjuntos de recursos apresentados nesta Legislatura. Na primeira apuração de dados, encontramos o seguinte resultado:

Tabela 1 - Recursos apresentados na $52^{\text {a }}$ Legislatura na CD

\begin{tabular}{|c|c|c|c|}
\hline & & Totais & Incidência - \% \\
\hline \multicolumn{2}{|c|}{ Total de recursos } & 315 & $100 \%$ \\
\hline \multicolumn{2}{|c|}{ Recursos Diversos $(*)$} & 211 & $67 \%$ \\
\hline Total de 104 & PDC - Parecer Normativo 09/90 - CCJ & 07 & $2 \%$ \\
\hline \multirow{2}{*}{$\begin{array}{l}\text { Recursos } \\
\text { Conclusivos }\end{array}$} & PL - art. 133, RICD & 35 & $11 \%$ \\
\hline & PL - art. $132, \S 2^{\circ}$, RICD & 62 & $20 \%$ \\
\hline
\end{tabular}

(*) recursos diversos: contra devolução de projetos, contra despachos e requerimentos entre outras decisões da presidência inclusive contra decisão da presidência por não concessão de palavra, questões de ordem, recursos a pareceres terminativos, destacados os recursos contra o poder conclusivos das comissões.

Graficamente podemos representar esta incidência da seguinte forma: 


\section{Gráfico 1 - Análise dos recursos apresentados na 52 ${ }^{\mathrm{a}}$ Legislatura da CD}

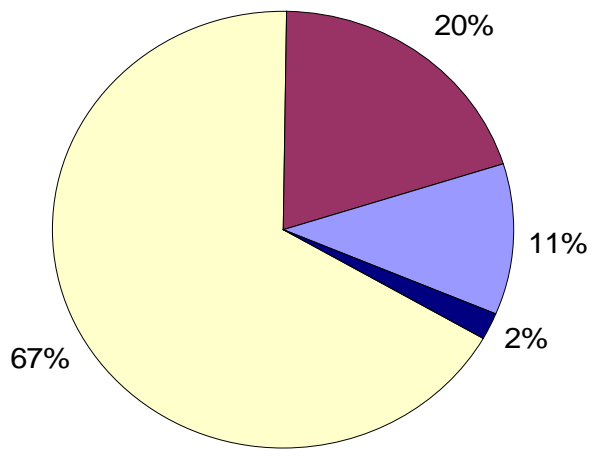

$\square$ Recursos Diversos

$\square$ Rec. Conclusivos (PL - art. 132, § 2º RICD)

$\square$ Rec. Conclusivos (PL - art. 133, § 2 , RICD)

- Rec. Conclusivos (PDC - PN 09/90 CCJR)

Esse total de 104 recursos interpostos contra a apreciação conclusiva das comissões apurados correspondem a 33\% dos recursos apresentados neste período. Eles modificaram a tramitação de 91 proposições principais (entre projetos de lei e projetos de decreto legislativo). Observamos, na pesquisa, a ocorrência de apresentação de mais de um recurso para uma mesma proposição apenas nos casos apurados do art. 132, § $2^{\circ}$. Assim, observamos que há razões diferentes para a interposição dos recursos. Por se tratar de fundamentos regimentais distintos, trataremos cada caso separadamente.

\subsection{Recursos a Projetos de Decreto Legislativo - PDC - uma exceção}

Os projetos de decreto legislativo são, em regra, proposições sujeitas à apreciação de Plenário. Porém, há casos em que essas proposições tramitam com poder conclusivo. Pacheco argumenta que os projetos de decreto legislativo destinados a ratificar atos de concessões de rádio e TV, por força do Parecer Normativo 09/91 da Comissão de Constituição e Justiça e Redação - CCJR, também se sujeitam ao poder pleno das comissões (Pacheco, 2005, p. 66).

O Parecer Normativo no 09/90 apresenta a seguinte situação: caso as decisões das comissões competentes concluam pela não-renovação, necessariamente o projeto será apreciado em Plenário, independentemente de recurso. Porém, assegura o parecer que as proposições que concluírem pela outorga, pela não-outorga e pela renovação do serviço tramitarão de forma conclusiva nas comissões temáticas, indo ao Plenário apenas por recurso.

Desta forma, coletamos e discriminamos os seguintes dados:

Tabela 2 - Projetos de Decreto Legislativo aprovados nas Comissões e os recursos ao Plenário na 52 Legislatura na $\mathrm{CD}$

\begin{tabular}{|c|c|c|c|c|c|}
\hline Sessão Legislativa & 2003 & 2004 & 2005 & 2006 & $\begin{array}{c}\text { Total na } \\
52^{\mathrm{a}} \text { Legislatura }\end{array}$ \\
\hline Total de PDC aprovados conclusivamente & 556 & 1472 & 399 & 411 & 2838 \\
\hline 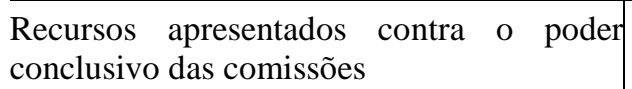 & 02 & 03 & 01 & 01 & 07 \\
\hline
\end{tabular}


Como podemos observar, a incidência do recurso ao Plenário é insignificante em relação às demais proposições da mesma natureza. Do total apurado de 2.838 proposições aprovadas conclusivamente, apenas 7 projetos de decreto legislativo sofreram recurso para serem submetidas ao Plenário.

Expressando graficamente, temos:

\section{Gráfico 2 - Incidência dos recursos apresentados a Projetos de Decreto Legislativo - PDC na CD na 52 ${ }^{\mathrm{a}}$ Legislatura}

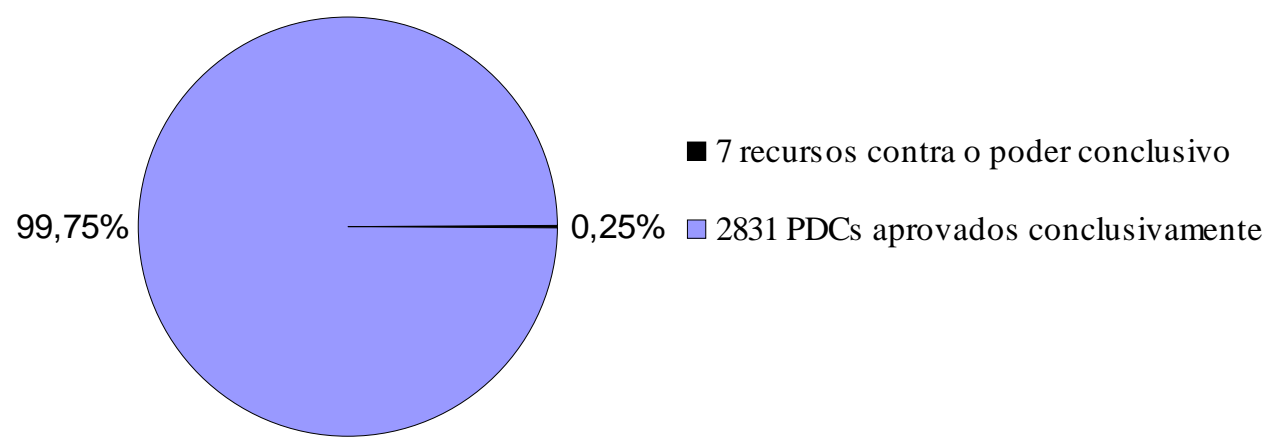

Nesses casos, os projetos se transformam em Decretos Legislativos. Entre os que receberam recursos nesta Legislatura, três deles já se desvencilharam dos recursos e se transformaram em Decretos Legislativos.

Se compararmos o total de 2.831 PDCs aprovados conclusivamente com 7 PDCs sobrestados por interposição de recurso, temos uma percentagem insignificante de $0,25 \%$. Tais dados estatísticos são relevantes porque, uma vez que estas proposições tramitam conclusivamente, encontram-se em situação semelhante aos projetos de lei que são objeto da nossa análise. Nesse caso, é importante observar que 2.831 proposições que deveriam ter sido apreciadas em Plenário, por força do Parecer Normativo 09/90 - CCJR, tramitaram conclusivamente apenas nas comissões. Esta delegação às comissões da Comissão de Justiça é uma exceção regimental que fortalece o trabalho de comissões, agiliza a tramitação dos PDCs e, principalmente, desobstrui os trabalhos de Plenário.

\subsection{Recursos a Projetos de Lei fundamentados no art. 133 do RICD}

Regra geral, as proposições que tramitam sob o regime das comissões e recebem pareceres contrários quanto ao mérito de todas as comissões são consideradas rejeitadas e arquivadas, art. 133, salvo recurso previsto no art. $132, \S 2^{\circ}$, do Regimento Interno. Portanto, elas e os recursos foram identificados nos nossos estudos.

Ao longo da coleta e organização dos dados apresentados, percebemos a grande 
incidência de proposições com recurso sob o fundamento do art. 133, que, consequentemente, apresentavam razões de existência diversa do clássico caso de recursos à apreciação conclusiva. Por esta razão, os separamos para apresentação.

Apresentamos, a seguir, as proposições que, apreciadas conclusivamente, receberam pareceres contrários de mérito. Destas, destacamos os 35 recursos interpostos, por sessão legislativa. Assim, apuramos o seguinte resultado:

Tabela 3 - Projetos de Lei sujeitos ao arquivamento e os recursos ao Plenário na 52a Legislatura da CD

\begin{tabular}{l|c|c|c|c|c}
\hline \multicolumn{1}{c|}{ Sessão Legislativa } & $\mathbf{2 0 0 3}$ & $\mathbf{2 0 0 4}$ & $\mathbf{2 0 0 5}$ & $\mathbf{2 0 0 6}$ & $\begin{array}{c}\text { Total na } \\
\mathbf{5 2}\end{array}$ \\
\hline $\begin{array}{l}\text { PLs sugislatura } \\
\text { arquivamento }\end{array}$ & 165 & 163 & 238 & 305 & 871 \\
\hline Recursos ao Plenário & 14 & 06 & 10 & 05 & 35 \\
\hline
\end{tabular}

Graficamente podemos expressar:

Gráfico 3 - Incidência dos recursos apresentados a Projetos de Lei - PL sujeitos ao arquivamento (art. 133, RICD) na CD na 52 ${ }^{\text {a }}$ Legislatura

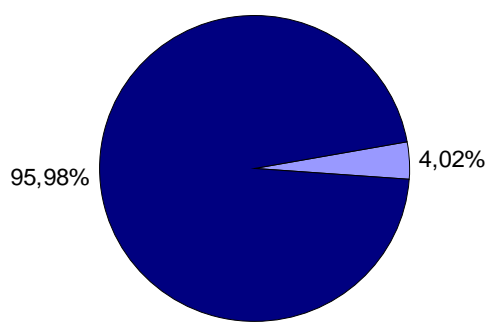

$\square 35$ recursos contra o poder conclusivo

- 836 PLs sujeitos ao arquivamento ( art. 133 do RICD)

Da análise do gráfico, temos: do total de 871 proposições prontas para arquivamento pelo art. 133, foram destacadas 35 que receberam recurso constitucional. Podemos observar que, nestes casos, o argumento para a propositura do recurso é o "não arquivamento" do projeto de lei.

A apresentação do recurso tem por utilidade dar uma sobrevida às proposições "fracassadas" em sua análise. Isto porque dos 35 recursos apresentados, 25 deles tiveram como primeiro signatários os próprios autores da proposição principal. Numa análise mais detalhada, provavelmente, entre os demais signatários dos 10 recursos restantes também poderá constar o autor do projeto de lei.

Os recursos devem ser apresentados por dez por cento dos parlamentares de cada Casa. Porém, nem a Constituição nem o Regimento Interno exigem uma fundamentação de mérito para propositura do recurso. Desta forma, há grande parte dos recursos que se apresentam sem fundamentação. E quando o fazem, em regra, usam argumentos que defendem o mérito da 
proposição principal, além das razões de relevância, complexidade e abrangência da matéria.

Ao longo da análise, percebemos que este grupo de recursos obedece a um comportamento muito peculiar de apenas dar sobrevida dos projetos fadados ao arquivamento. De toda forma, os projetos ficam sobrestados, esperando a votação do recurso em Plenário, o que nunca ocorre.

Em regra, ao final da Legislatura, esses recursos e os respectivos projetos são arquivados, nos termos do art. 105 do Regimento Interno. Criou-se, para esta categoria de proposições com pareceres contrários de comissão, uma falsa expectativa de apreciação plenária. O que realmente ocorre é uma protelação do arquivamento.

\subsection{Recursos a Projetos de Lei fundamentados no art. 132, $\$ 2^{\circ}$ do RICD}

Analisemos, enfim, o clássico recurso ao poder pleno das comissões, nos termos do art. $58 \S 2^{\circ}$, I, da Constituição Federal c/c art. 132, § $2^{\circ}$ do Regimento Interno da Câmara dos Deputados. Seguindo a mesma linha de raciocínio, primeiro identificamos os projetos aprovados conclusivamente nas comissões e destacamos aqueles com recursos, apresentando-os por Sessão Legislativa. Assim, obtivemos o seguinte resultado:

Tabela 4 - Projetos de Lei aprovados conclusivamente em comissões e os recursos ao Plenário na 52a Legislatura na CD

\begin{tabular}{l|c|c|c|c|c}
\hline Sessão Legislativa & $\mathbf{2 0 0 3}$ & $\mathbf{2 0 0 4}$ & $\mathbf{2 0 0 5}$ & $\mathbf{2 0 0 6}$ & $\begin{array}{c}\text { Total na } \\
\text { 52 }\end{array}$ \\
\hline $\begin{array}{l}\text { PLs apreciados } \\
\text { conclusivamente nas } \\
\text { comissões }\end{array}$ & 71 & 75 & 137 & 124 & 407 \\
\hline $\begin{array}{l}\text { PLs que sofreram } \\
\text { recurso } \\
\text { constitucional }\end{array}$ & 09 & 02 & 15 & 23 & 49 \\
\hline $\begin{array}{l}\text { Recursos } \\
\text { Constitucionais } \\
\text { Ao Plenário }\end{array}$ & $15(*)$ & 02 & $20(* *)$ & $25(* * *)$ & 62 \\
\hline
\end{tabular}

A diferença de número de PL que sofrem recurso constitucional com o número de recursos interposto tem a seguinte explicação: (*) Em 2003 - interpostos 5 recursos ao PL 379/2003 e 3 recursos ao PL 5329/2002

(**) Em 2005 - interpostos 2 recursos aos PL 6482/2002, PL 4497/2004 e PL 22/2003 e 3 recursos ao PL 5100/2005

(***) Em 2006 - interpostos 2 recursos ao PL 2654/2003 e ao PL 4734/2004

$\mathrm{Na}$ análise gráfica: 
Gráfico 4 - Incidência dos recursos contra o poder conclusivo apresentados a

Projetos de Lei - PLs aprovados nas comissões (art. 132, § $2^{\circ}$, RICD)

na CD na $52^{\mathrm{a}}$ Legislatura

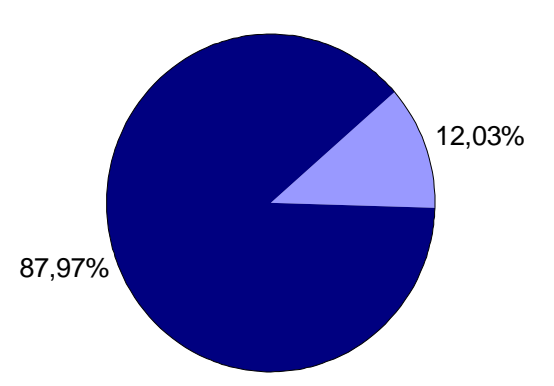

$\square 49$ PLs sobrestados por recurso contra o poder conclusivo

— 358 PLs apreciados conclusivamente sem interposição de recursos

Como podemos observar, no universo de $4.07^{2}$ projetos de lei apreciados e aprovados conclusivamente nas comissões, destacamos 49 proposições que sofreram recursos para a perda do poder pleno de decisão das comissões. Sobrestou-se, então, o andamento desses projetos em favor da tramitação do recurso (proposição acessória). Assim, conforme o Gráfico 4, do total de proposições com apreciação concluída nas comissões, 87,97\% seguiram sua trajetória natural, ou seja, foram remetidos ao Senado Federal ou à sanção. Os 49 projetos destacados, que representam 12,03\% do total, receberam recurso contra a deliberação plena das comissões. Assim, foram sobrestados os projetos de lei em favor da tramitação dos acessórios.

Ainda na análise da tabela de dados acima apresentada, destacamos que foram interpostos 62 recursos a esses 49 projetos de lei sobrestados, uma vez que a mesma proposição pode receber mais de um recurso, contanto que contenham o número mínimo de assinaturas exigidas. Vamos considerar apenas o primeiro recurso apresentado a cada proposição, já que a sua interposição é a razão da modificação do andamento do principal e os demais recursos apresentados são apensados para tramitação conjunto, art. 142, RICD.

Portanto, com este raciocínio temos a primeira conclusão: os 62 recursos interpostos nos termos do art. 58 da Carta Magna sobrestaram o andamento de 49 proposições já apreciadas e concluídas nas comissões da Câmara dos Deputados na $52^{\mathrm{a}}$ Legislatura. Isto corresponde a uma paralisação de $12,03 \%$ dos trabalhos concluídos em comissão, o que por si só já é muito representativo.

Seguimos, então, a análise destes dados na $52^{\mathrm{a}}$ Legislatura: 2 recursos foram providos, 25 arquivados e 22 ainda tramitavam. Discriminando-os por Sessão Legislativa temos:

2

Somatório do $\mathrm{n}^{\mathrm{o}}$ de proposições apreciadas e aprovadas conclusivamente que não sofrem a interposição de recurso e proposições, também apreciadas e aprovadas conclusivamente, que sofrem a interposição do recurso. 
Tabela 5 - Recursos fundados no art. $132, \S 2^{\circ}$, ao final da $52^{\mathrm{a}}$ Legislatura na CD

\begin{tabular}{|c|c|c|c|c|c|}
\hline Sessão Legislativa & 2003 & 2004 & 2005 & 2006 & $\begin{array}{c}\text { Total na } \\
52^{\mathrm{a}} \text { Legislatura }\end{array}$ \\
\hline $\begin{array}{l}\text { Total de recursos } \\
\text { apresentados }(*)\end{array}$ & 09 & 02 & 15 & 23 & 49 \\
\hline Rec. em tramitação. & 02 & - & 09 & 11 & 22 \\
\hline $\begin{array}{l}\text { Rec. Arquivados sem } \\
\text { apreciação plenária }\end{array}$ & 07 & 02 & 05 & 11 & 25 \\
\hline $\begin{array}{l}\text { Rec. Apreciados } \\
\text { em Plenário e } \\
\text { arquivados }\end{array}$ & - & - & $01(* *)$ & $01(* * *)$ & 02 \\
\hline
\end{tabular}

(*) considerando-se apenas o primeiro recurso apresentado a cada proposição.

(**) REC 257/2005 ao PL 5318/2005

(***) REC 265/2006 ao PL 73/1999

Com estes dados observamos os resultados graficamente:

Gráfico 5 - Situação dos recursos contra o poder conclusivo (art.132, § 2, RICD) na CD ao final da $52^{\mathrm{a}}$ Legislatura

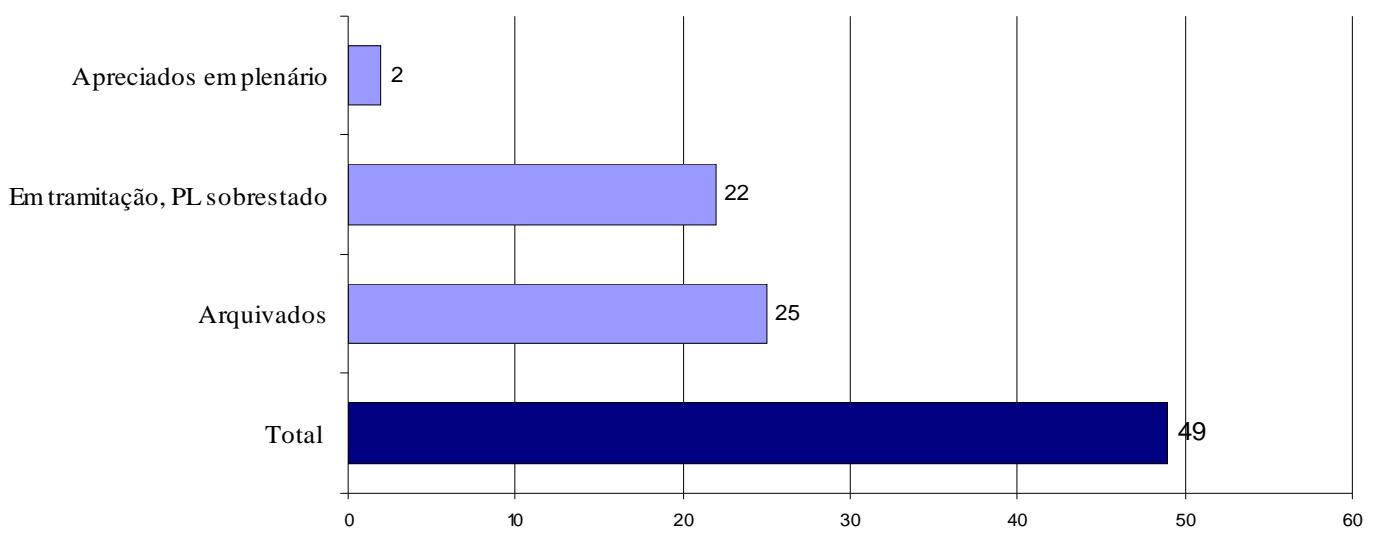

Assim, com os dados apurados temos três grupos:

$1^{\circ}$ - 2 recursos, que em sendo apreciados, foram providos, e, em seguida arquivados. Levou-se a questão temática principal à análise do Plenário da Câmara dos Deputados. São eles: REC 257/2005 ao PL 5318/2005 e o REC 265/2006 ao PL 73/1999. As razões dessas apreciações serão oportunamente estudadas, mas, de toda forma, correspondem a 4,1\% dos recursos apreciados em Plenário;

$2^{\mathrm{o}}$ - 22 recursos, correspondentes a 44,89\% do total apresentado, seguiram tramitando para a $53^{\text {a }}$ Legislatura, e por consequiência encerraram aquela Legislatura sobrestando os projetos de lei correspondentes; e

$3^{\circ}$ - 25 recursos, que representam 51,01\% desse total, foram arquivados. Neste grupo encontram-se: os devolvidos ou arquivados por não conter número mínimo, arquivados por 
retirada de assinaturas, os casos de aprovação de urgência ao PL sem apreciação plenária do recurso e um projeto de lei prejudicado, que, por conseqüência, prejudicou o acessório. Assim, com o arquivamento dos recursos os projetos de lei correspondentes, após a feitura da redação final, seguiram seu trâmite: para o Senado Federal ou à sanção.

Seguimos, portanto, para uma análise pontual de cada um desses grupos.

\subsubsection{Recursos providos em Plenário ao término da Legislatura}

Durante toda a $52^{\mathrm{a}}$ Legislatura, como vimos, somente dois recursos foram providos com fundamento constitucional contra o poder pleno das comissões: o Recurso ${ }^{\circ}$ 257/2005 ao Projeto de Lei $n^{\circ}$ 5318/2005 e o Recurso ${ }^{\circ}$ 265/2006 ao Projeto de Lei $n^{\circ} 73 / 1999$.

Apresentado em 2005, o Recurso $n^{\circ}$ 257/2005 ao Projeto de Lei $n^{\circ} 5318 / 2005$ foi provido em Plenário, em 12 de dezembro de 2006, após constar como "matéria sobre a Mesa" por 11 vezes e ser sobrestado por 3 medidas provisórias.

Ocorre que, na mesma sessão em que foi apreciado e provido o recurso contra o poder conclusivo das comissões, houve, logo em seguida, aprovação do requerimento de urgência do senhor Deputado Miro Teixeira. O êxito do recurso somente ocorreu porque as lideranças pretendiam votar rapidamente o projeto de lei supracitado na sessão seguinte, porque a aprovação do recurso não era razão suficiente de inclusão e apreciação do projeto de lei. Corriase o risco de, mesmo a proposição constando da pauta, ser preterida por outras matérias com preferência regimental.

Dessa forma, a aprovação do recurso constitucional para a apreciação do projeto de lei em Plenário, por si só, não era bastante para que a matéria fosse de fato pautada e apreciada. As lideranças estavam motivadas a realmente apreciar o projeto de lei, quando aprovou-se, então, a "urgência", instrumento regimental de extrema eficiência para o fim pretendido - fato este incontroverso, pois consta das notas taquigráficas, quando das palavras do Presidente Deputado Inocêncio Oliveira e do Deputado Miro Teixeira, Líder, a discussão do momento que precede a votação do recurso:

SR. PRESIDENTE (Inocêncio Oliveira) - Informo aos Srs. Deputados que foi feito um acordo nos seguintes termos: aprovaríamos o recurso, o projeto voltaria ao Plenário e seria emendado para que pudesse atender ao dispositivo. Concedo a palavra ao ilustre Líder, Deputado Miro Teixeira. O SR. MIRO TEIXEIRA (PDT-RJ. Pela ordem. Sem revisão do orador.) Sr. Presidente, conversei agora com o Líder Arlindo Chinaglia. Esse acordo também diz respeito à volta do projeto, a estar na pauta da Ordem do Dia de amanhã. É isto?

SR. PRESIDENTE (Inocêncio Oliveira) - Concordo com Vossa Excelência. É isso. (Diário da Câmara dos Deputados, 13 dez 2006, p. 55009-55010)

E, neste contexto, o recurso foi provido porque sobrestava o projeto principal e havia vontade política para se apreciar o projeto em plenário. Não era possível pedir-se "urgência" 
para uma proposição nesta condição. Assim, ela foi estrategicamente aprovada logo na seqüência para dar celeridade ao trâmite. Em 13 de dezembro de 2006, foi remetida ao Senado Federal. Em 20 de junho de 2007, transformada na Lei nº 11.493/2007.

Por todo o exposto, se o recurso não fosse provido, o projeto não poderia ser apreciado em plenário, porém não há conseqüências do provimento do recurso, já que doravante a tramitação ocorreu em regime de "urgência". Os reflexos advindos da apresentação desse recurso estão descaracterizados.

Também o Recurso no 265/2006 ao Projeto de Lei nº 73/1999 foi, em 2006, apreciado em Plenário. Apresentado em 14 de fevereiro de 2006, constou 10 vezes como "matéria sobre a Mesa”, sendo sobrestado 4 vezes pela MPV 275/2005. Foi provido no dia 21 de março de 2006. Cumprida a função de encaminhar a matéria à deliberação do Plenário, o recurso foi arquivado em 24 de maio de 2006. Único recurso encontrado que tramitou com celeridade e sem solicitação de regime de "urgência".

Por conseguinte, o projeto de lei seguiu para apreciação plenária, mas somente em 20 de novembro de 2008, a proposição principal foi definitivamente aprovada na Câmara dos Deputados e remetida ao Senado Federal. Destaque-se que a proposição aprovada pelas comissões na $52^{\mathrm{a}}$ Legislatura, apenas foi apreciada em Plenário na $53^{\mathrm{a}}$ Legislatura. Da aprovação do recurso à aprovação da matéria em Plenário transcorreu-se dois anos e oito meses. Isto acontece porque o projeto de lei não tem preferência na pauta plenária. Houve pedido de "urgência" a este projeto de lei em 04 de julho de 2007.

Esta tramitação na Câmara dos Deputados está tecnicamente concluída, salvo emendas do Senado Federal, que eventualmente tramitarão na Casa. Até o encerramento da nossa coleta de dados, a proposição, remetida ao Senado Federal, ainda se encontrava em tramitação. Dessa forma, o projeto ainda está sujeito à análise legislativa e a alterações de toda ordem.

Está demonstrado o sobrestamento da proposição legislativa por apreciação de medidas provisórias. O Projeto de Lei $\mathrm{n}^{\circ}$ 73/1999, na sua tramitação legislativa, também sofreu retirada de pauta por acordo de líderes, mas foi, enfim, definitivamente aprovado na Casa em 20 de novembro de 2008, mesma data que seguiu ao Senado Federal. Apesar disso, não há como se verificar a influência do Executivo neste caso, já que o trâmite legislativo não foi encerrado.

Das proposições principais apreciadas no Plenário, deste tópico, temos que: encerraram a tramitação sob "urgência" e o segundo ainda está sendo analisado no Senado Federal. Podemos concluir que, dentro desta $52^{\mathrm{a}}$ Legislatura, não temos casos de projetos de lei aprovados em Plenário, por força do recurso constitucional, art. 58, que tenha sido positivado, transformando-se em normas jurídicas.

De toda forma, esses 2 recursos aprovados em Plenário estão definitivamente arquivados, porque foram apreciados. Nesses casos, foram aprovados e cumpriram sua função de levar as proposições principais à análise do Plenário. 


\subsubsection{Recursos em tramitação ao término da Legislatura}

No final da Legislatura ainda encontravam-se em tramitação 44,89\% dos recursos apresentados na $52^{\mathrm{a}}$ Legislatura, ou seja, 22 proposições já apreciadas conclusivamente nas comissões ainda eram sobrestadas pela interposição dos respectivos recursos.

Destacados e analisados temos o desfecho desta tramitação até o fechamento da coleta de dados deste trabalho, outubro de 2009:

Tabela 6 - Análise da situação atual dos recursos "em tramitação" que foram apresentados na 52a Legislatura

\begin{tabular}{l|c|c|c|c|c|c}
\hline \multicolumn{1}{c|}{$\begin{array}{c}\text { Sessão } \\
\text { Legislativa }\end{array}$} & $\mathbf{2 0 0 3}$ & $\mathbf{2 0 0 4}$ & $\mathbf{2 0 0 5}$ & $\mathbf{2 0 0 6}$ & $\begin{array}{c}\text { Total na } \\
\mathbf{5 2} \text { Legislatura }\end{array}$ & $\begin{array}{c}\text { Situação } \\
\text { Atual }\end{array}$ \\
\hline $\begin{array}{l}\text { REC. } \\
\begin{array}{l}\text { Tramitando, } \\
\text { sobrestando-se o } \\
\text { PL }\end{array}\end{array}$ & 02 & - & 08 & 11 & 22 & 21 \\
\hline $\begin{array}{l}\text { REC. } \\
\text { ARQUIVADO }\end{array}$ & - & - & - & - & - & $01(*)$ \\
\hline
\end{tabular}

(*) REC 225/2005 ao PL 52/2003 - Proposição principal PREJUDICADA, 16/01/2007, art. 164, II, RICD, pela vigência da Lei Complementar n ${ }^{\circ}$ 123/2006.

Lembramos, por oportuno, que finda a legislatura, as proposições que receberam pareceres favoráveis de todas as comissões, nos termos do art. 105, I, do Regimento Interno, não serão sumariamente arquivadas, razão pela qual os recursos, proposições acessórias, também recebem esse tratamento.

Portanto, analisando-se os dados alcançados veremos que os recursos que atravessaram a $52^{\mathrm{a}}$ Legislatura, em tramitação, permaneceram, em regra, na mesma situação: tramitando e sobrestando os projetos principais.

Destacamos que apenas um desses recursos foi arquivado, porém por razões totalmente alheias a sua existência. É o caso do Recurso no 225/2005 ao Projeto de Lei $n^{\circ} 52 / 2003$, pois ocorreu a prejudicialidade da proposição, em 16 de janeiro de 2007, nos termos do art. 164, II, do Regimento Interno, pela vigência da Lei Complementar $n^{\circ}$ 123/2006.

Uma vez dada a proposição por prejudicada, ela é definitivamente arquivada pelo Presidente da Câmara, art. 164, § $4^{\circ}$ do Regimento Interno. Assim, também deverá ser arquivado o recurso, proposição acessória. ${ }^{3}$

Sobre o tema, destacamos Vieira:

O Presidente da Câmara dos Deputados ou de comissão pode declarar

\footnotetext{
${ }^{3}$ Nas fichas de "Consulta Tramitação das Proposições" na página da Câmara dos Deputados, o último andamento do REC 225/2005 está desatualizado, pois apresenta, em 11/10/2005, o seguinte andamento "Encaminhado à publicação..."
} 
prejudicada matéria pendente de deliberação pelo respectivo colegiado por haver esta perdido a oportunidade ou em razão de decisão anterior do órgão. Não havendo recurso contra tal declaração, a proposição será arquivada (Vieira, 2005, p. 34).

Para podermos ter uma visão mais global apresentamos o seguinte quadro analítico:

\section{Gráfico 6 - Situação atual dos recursos "em tramitação" ao término da $52^{\mathrm{a}}$ Legislatura na CD}

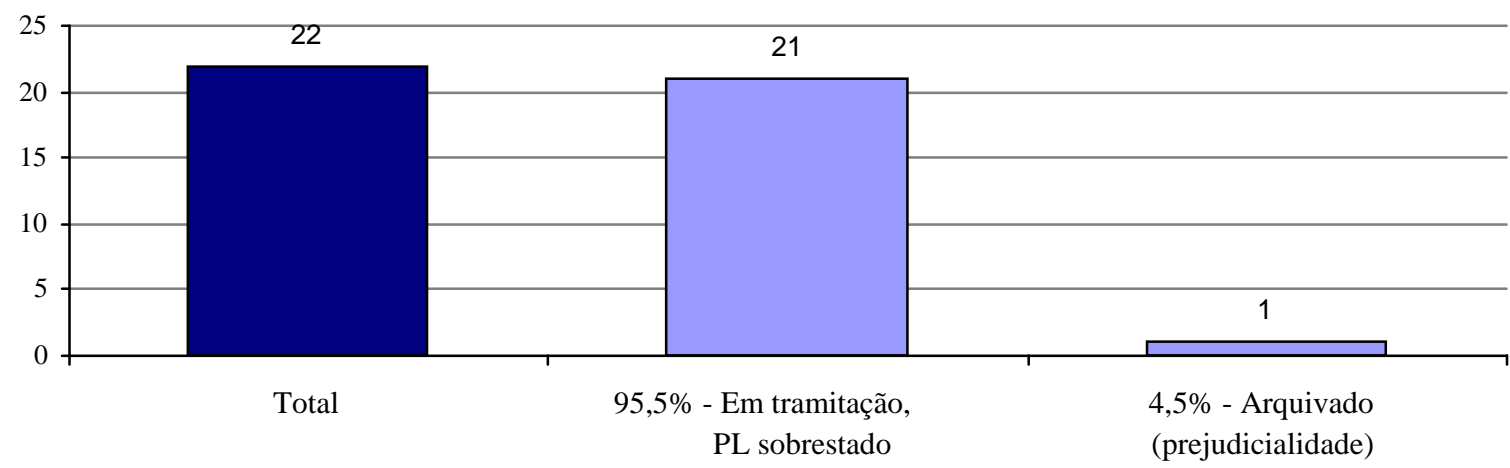

No gráfico 6, do total das 407 proposições aprovadas conclusivamente nas comissões, 49 projetos de lei sofreram recursos. Desses, apuramos que 21 proposições até hoje, em meados da $53^{\text {a }}$ Legislatura, continuam sobrestadas pela interposição desse recurso constitucional ao Plenário. Além desses que sobrestão o principal, destacamos um arquivado por prejudicialidade, pois por tempo de tramitação foi tão estendido a ponto de entrar em vigência a Lei Complementar acima citada.

Isto corresponde a dizer que esse grupo representa 5,40\% das proposições apreciadas conclusivamente nas comissões que tiveram suas tramitações e conclusões interrompidas por um recurso. Nesses casos, a utilidade única do recurso foi "paralisar" a tramitação legislativa do projeto, não dando seguimento legislativo ou à revisão do Senado Federal ou mesmo à sanção. Excluindo-se a possibilidade de, em revisão no Senado Federal ou na Câmara dos Deputados, aprovarem-se alterações, a interposição do recurso praticamente retira do ordenamento "leis" já analisadas e praticamente "acabadas" pela análise conclusiva das comissões.

\subsubsection{Detalhamento dos recursos "em tramitação"}

Esta incidência de 21 recursos sobrestando os projetos de lei corresponde a 42,85\% do total de 49 apresentados. Entendemos que os recursos contra o poder pleno das comissões deveriam ter prazos regimentais para sua apreciação, para que proposições nessa situação não tramitem eternamente, sobrecarregando o Plenário e seu sistema de tramitação. O fato se presta apenas para fragilizar a análise das comissões. 
Na Câmara dos Deputados, o recurso, uma vez admitido, receberá o seguinte despacho: "Publique-se. Submeta-se ao Plenário.” Após a publicação, no jargão legislativo, estão "prontos para a pauta". Isto quer dizer que podem ser incluídos a qualquer tempo na pauta do Plenário. E, quando estão na pauta, o termo corresponde utilizado é "Matéria sobre a Mesa" do Plenário; significa que estão pautados para apreciação daquela sessão plenária. Numa análise mais detalhada desses recursos "em tramitação", temos a seguinte situação:

Tabela 7 - Recursos que entraram na $53^{\mathrm{a}}$ Legislatura tramitando

\begin{tabular}{c|c|c|c|c|c}
\hline $\begin{array}{c}\text { Sessão Legislativa / } \\
\text { Resumo do andamento } \\
\text { dos recursos }\end{array}$ & $\mathbf{2 0 0 3}$ & $\mathbf{2 0 0 4}$ & $\mathbf{2 0 0 5}$ & $\mathbf{2 0 0 6}$ & $\begin{array}{c}\text { Total na } \\
\mathbf{5 2}^{\mathbf{a}} \\
\text { Legislatura }^{\text {(n) }}\end{array}$ \\
\hline $\begin{array}{c}\text { PRONTO PARA PAUTA } \\
\text { - em tramitação - }\end{array}$ & 2 & - & 7 & 10 & 19 \\
\hline $\begin{array}{c}\text { MATÉRIA SOBRE A MESA } \\
\text { - em tramitação - }\end{array}$ & - & - & - & 2 & 2 \\
\hline TOTAL DE RECURSOS & 2 & - & 7 & 12 & 21 \\
\hline
\end{tabular}

Dados apurados até outubro/2009

Excluindo-se os dois recursos já aprovados em Plenário e já analisados, que também constaram como "matéria sobre a Mesa", e o prejudicado, que já foram arquivados, podemos observar entre os 21 recursos prontos para serem incluídos na sessão plenária, que ainda tramitam na Câmara dos Deputados, apenas 2 deles constam como "matéria sobre a Mesa".

Analisando esses 2 recursos incluídos na pauta plenária, temos:

- REC no 313/2006 - constou 38 vezes como "Matéria sobre a Mesa" - tendo sido sobrestado 19 vezes por MPVs.

- REC no 314/2006 - constou 32 vezes como "Matéria sobre a Mesa" - tendo sido sobrestado 16 vezes por MPVs. Por fim, houve solicitação de urgência, requerimento de retirada de assinaturas ou do próprio recurso e arquivamento. Tramitando por urgência o PL $\mathrm{n}^{\circ}$ 2.550/2003 foi transformado na Lei $n^{\circ} 11.877 / 2008$, com veto presidencial parcial, a ser apreciado.

De tudo isso, podemos concluir:

$1^{\circ}$ - Em regra, os recursos não são incluídos na pauta plenária.

$2^{\circ}$ - Nas poucas vezes em que acontece de os recursos serem pautados, sua votação é protelada e preterida por diversas razões, como: encerramento da sessão, cancelamento da ordem do dia, acordo de líderes e, especialmente, pelo sobrestamento, decorrente do esgotamento do prazo para apreciação de medidas provisórias.

Portanto, da 52 $2^{\mathrm{a}}$ Legislatura restam 20 proposições que ainda se encontram "em tramitação legislativa”. Assim, há inércia legislativa sobre os recursos, já que o regimento interno não determina prazo para a sua apreciação, apesar de que não podemos esquecer que estamos tratando de parlamento onde os processos são movidos por força de vontade política. 


\subsubsection{Recursos arquivados ao término da Legislatura}

Neste grupo de recursos apresentados na $52^{\mathrm{a}}$ Legislatura e atualmente arquivados, temos 29 ocorrências. Esse arquivamento ocorre por diversas razões: devolvidos ou arquivados por não conter número mínimo; arquivados por retirada de assinaturas; aprovação de urgência ao PL sem apreciação plenária do recurso; prejudicados e, ainda, os aprovados em Plenário, já que uma vez cumprida sua função de levar a proposição à apreciação plenária, o recurso será arquivado. Discriminando-os, temos:

Tabela 8 - Recursos arquivados após a $52^{\mathrm{a}}$ Legislatura

\begin{tabular}{c|c|c|c|c|c}
\hline $\begin{array}{c}\text { Sessão Legislativa / Resumo do } \\
\text { andamento dos recursos }\end{array}$ & $\mathbf{2 0 0 3}$ & $\mathbf{2 0 0 4}$ & $\mathbf{2 0 0 5}$ & $\mathbf{2 0 0 6}$ & $\begin{array}{c}\text { Total na } \\
\mathbf{5 2}^{\mathbf{a}} \text { Legislatura }\end{array}$ \\
\hline $\begin{array}{c}\text { Devolvido ao autor ou arquivado por } \\
\text { não conter número mínimo de } \\
\text { assinaturas (art. 58, } \S 3^{\circ} \text { c/c } 132, \S 2^{\circ} \text { do } \\
\text { RICD) }\end{array}$ & 3 & - & 1 & 3 & 7 \\
\hline $\begin{array}{c}\text { PRONTO PARA PAUTA } \\
\text { Deferido requerimento de retirada de } \\
\text { assinaturas - Arquivo }\end{array}$ & 4 & 2 & 5 & 5 & 16 \\
\hline $\begin{array}{c}\text { PRONTO PARA PAUTA } \\
\text { Aprovada urgência sem apreciação do } \\
\text { recurso. Rec. Arquivado } \\
\text { Aprovado regime de urgência }\end{array}$ & - & - & - & 1 & 1 \\
\hline $\begin{array}{c}\text { PRONTO PARA PAUTA } \\
\text { Aprovada urgência sem apreciação do } \\
\text { recurso. Rec. Arquivado. }\end{array}$ & - & - & - & 2 & 2 \\
\hline $\begin{array}{c}\text { PRONTO PARA PAUTA } \\
\text { Prejudicado. Rec. Arquivado }\end{array}$ & - & - & 1 & - & 1 \\
\hline $\begin{array}{c}\text { MATÉRIA SOBRE A MESA } \\
\text { Recurso aprovado e arquivado }\end{array}$ & - & - & 1 & 1 & 2 \\
\hline TOTAL DE RECURSOS & 7 & 2 & 8 & 12 & 29 \\
\hline
\end{tabular}

Assim, os arquivados ao término da $52^{\mathrm{a}}$ Legislatura representam $59,18 \%$ do total de recursos principais apresentados, ou seja, mais da metade dos apresentados nos termos do art. $132, \S 2^{\circ}$, do Regimento Interno.

Esses arquivamentos que ocorreram por faltar o número mínimo de assinaturas e por retirada de assinaturas obedecem aos termos do art. $102, \S 4^{\circ}$, ou pelo art. $104, \S 2^{\circ}$, c/c art. 114 , VII, todos do Regimento Interno da Câmara dos Deputados.

Se para apresentação do recurso precede-se o apoiamento de dez por cento dos parlamentares, para a apresentação de requerimento de retirada dos recursos, são necessários metade mais um dos subscritos. Ora, se há interesse parlamentar para a positivação destas matérias, eles se mobilizariam para a retirada do recurso, liberando-se o projeto para tramitar. E, se há interesse em apreciação plenária, a prática tem demonstrado que a solicitação de urgência é o meio mais eficiente. 


\subsubsection{Análise da tramitação dos Projetos de Lei aos quais os recursos foram arquivados}

Os 29 projetos de lei aqui analisados correspondem a todos aqueles que retornam a sua tramitação. Estão incluídos os projetos com recursos aprovados em Plenário e aqueles projetos com recursos arquivados nos moldes da sessão anterior, que vão à feitura da redação final na Comissão de Constituição, Justiça e Redação, para, então, seguir seu trâmite: ao Senado Federal ou à sanção. Vamos, acompanhando o andamento destas proposições, encontrar as várias possibilidades dessa conclusão legislativa:

Tabela 9 - Análise dos resultados alcançados pelos Projetos de Lei aos quais os recursos foram arquivados ao término da $52^{\mathrm{a}}$ Legislatura na $\mathrm{CD}$

\begin{tabular}{l|c|c|c|c|c|c}
\hline \multicolumn{1}{c|}{ Sessão Legislativa } & $\mathbf{2 0 0 3}$ & $\mathbf{2 0 0 4}$ & $\mathbf{2 0 0 5}$ & $\mathbf{2 0 0 6}$ & $\begin{array}{c}\text { Situação } \\
\text { Atual }\end{array}$ & $\begin{array}{c}\text { Incidência } \\
(\%)\end{array}$ \\
\hline $\begin{array}{l}\text { Totais dos Recursos } \\
\text { arquivados }\end{array}$ & 7 & 2 & 8 & 12 & 29 & $100 \%$ \\
\hline PL tramitando na CD & - & - & 1 & - & 1 & $3,25 \%$ \\
\hline PL tramitando no SF & 2 & 1 & - & 3 & 6 & $21 \%$ \\
\hline PL arquivado no SF & 1 & - & - & - & 1 & $3,25 \%$ \\
\hline $\begin{array}{l}\text { Veto Presidencial Total } \\
- \text { mantido }\end{array}$ & 1 & - & 2 & 3 & 6 & $21 \%$ \\
\hline $\begin{array}{l}\text { Sanção com Veto } \\
\text { Parcial - mantido }\end{array}$ & 1 & - & 2 & $3(*)$ & 6 & $21 \%$ \\
\hline $\begin{array}{l}\text { Sanção com Veto } \\
\text { Parcial - a ser apreciado }\end{array}$ & - & - & - & $1(*)$ & 1 & $3,25 \%$ \\
\hline $\begin{array}{l}\text { Sanção integral } \\
\text { PLe Recurso }\end{array}$ & - & - & 1 & - & 1 & $3,25 \%$ \\
\hline
\end{tabular}

(*) Tramitaram em regime de urgência os Projetos de Lei n. ${ }^{\circ}$ s 2.550/2003, 5.318/2005, 5.848/2005 e $6.467 / 2005$.

Dá análise do quadro, podemos concluir que dos projetos de lei que voltaram a tramitar após arquivamento dos recursos, 1 ainda tramita na Câmara dos Deputados; dos enviados para o Senado Federal, 7 deles, ou seja 24,25\%, também não lograram êxito. No Senado, 6 encontramse tramitando e 1 foi arquivado. Somando-se a estes, os que sofreram Veto Presidencial Total - 
mantido, 6 ocorrências, que correspondem a $21 \%$ do total, encontramos 14 projetos de lei, representando 48,50\% de proposições aprovadas conclusivamente nas comissões, e, após recurso constitucional arquivado, seguiram seu curso natural de tramitação legislativa e, mesmo assim, não se transformaram em norma jurídica. Considerando ainda a proposição prejudicada, temos o total de 15 projetos que não lograram êxito, correspondentes a 51,75\%.

Podemos também agrupar os dados da seguinte forma:

Gráfico 7 - Situação atual das proposições as quais os recursos conclusivos foram arquivados ao término da $52^{\mathrm{a}}$ Legislatura na CD

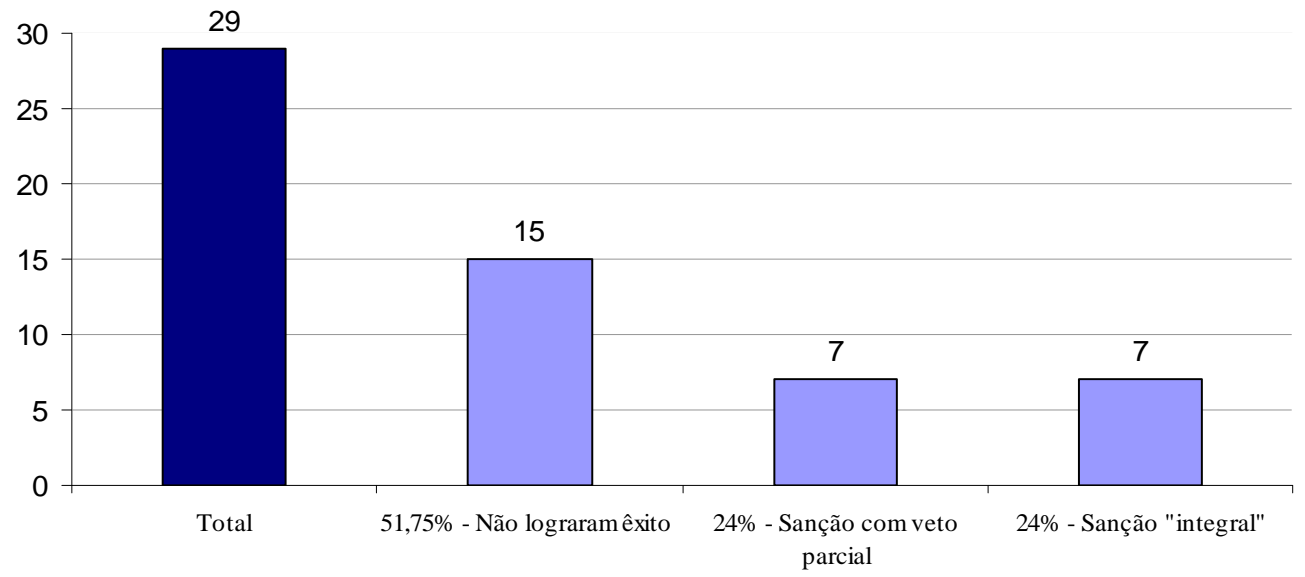

Portanto, analisando-se o Gráfico 7 do grupo de 29 recursos que foram arquivados, observamos que, praticamente a metade, $48 \%$ das proposições, recuperaram seu trâmite natural após o arquivamento dos recursos, transformando-se em normas jurídicas conforme elaboração legislativa plena, mesmo que vetadas parcialmente.

\subsubsection{Análise comparativa dos dados apurados}

Os Projetos de Decreto Legislativo e os Projetos de Lei fundados no art. 133 que recebem recursos ao final da tramitação em comissões, analisados nos itens 6.3.1. e 6.3.2., não correspondem aos resultados que perseguimos.

O primeiro grupo originará Decreto Legislativo que não está sujeito à sanção presidencial. O segundo grupo, apesar de estar entre as proposições sujeitas à apreciação plena com abertura de prazo regimental, com a apresentação do recurso ao fim dos trabalhos em comissão, funda-se na iminente possibilidade de arquivamento da proposição que receberá todos os pareceres contrários.

Essa é a razão pela qual destacamos para análises globais, neste capítulo, apenas os recursos apresentados nos termos do art. 58, $\S 2^{\circ}$, I da Constituição Federal c/c art. 132, § $2^{\circ}$, do Regimento Interno da Câmara dos Deputados, que correspondem aos projetos já aprovados nas comissões temáticas que, pela interposição do recurso, perdem esta condição, Seção 6.3.

Das 407 proposições apreciadas conclusivamente nas comissões na 52 $2^{\mathrm{a}}$ Legislatura, 49 
projetos de lei sofreram a interposição desse recurso. Apresentaremos graficamente a proporção entre o número de proposições aprovadas nas comissões temáticas em relação à progressão dos recursos interpostos. Isto corresponde a dizer que, com esta ação recursal, o poder pleno foi negado, em média, a 12,03\% daquelas proposições já aprovadas. Um índice, a nosso ver, muito representativo.

Gráfico 8 - Análise anual dos projetos aprovados conclusivamente nas comissões e dos recursos apresentados em cada sessão Legislativa na $52^{a}$ Legislatura da $\mathbf{C D}$

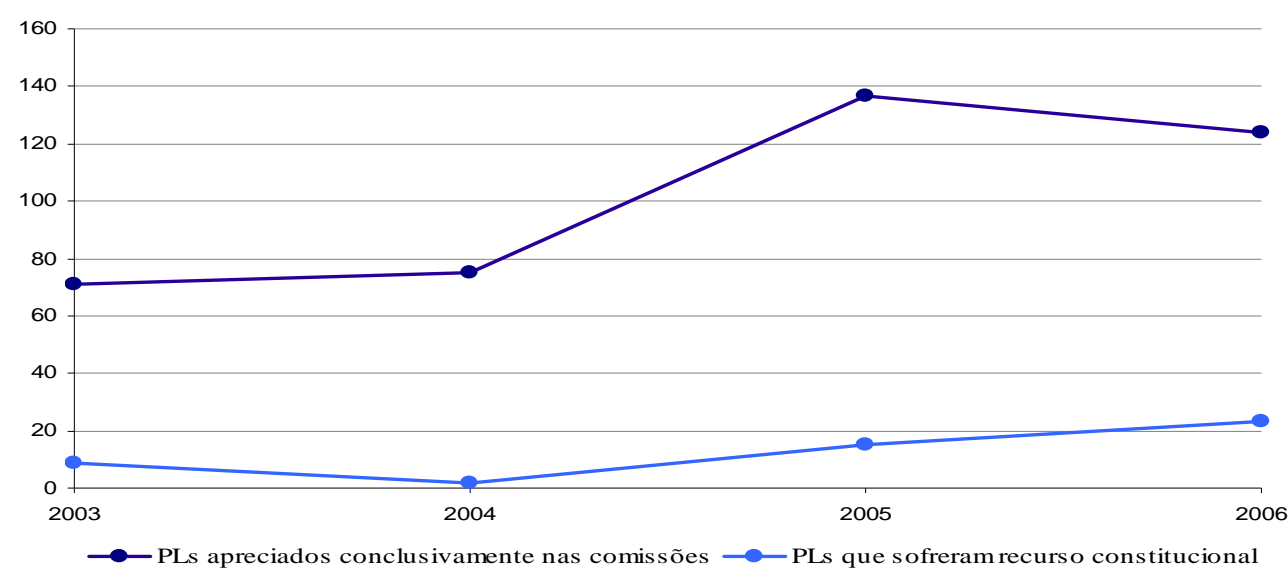

Da análise do Gráfico 8, observamos que a interposição do recurso obedece um padrão de apresentação próximo da média da Legislatura. Ao término da $52^{a}$ Legislatura, a situação em que se encontravam era a seguinte:

Tabela 10 - Análise percentual do andamento dos recursos ao final da $52^{\mathrm{a}}$ Legislatura na CD

\begin{tabular}{l|c|c}
\hline \multicolumn{1}{|c|}{$\begin{array}{c}\text { Quant. } \\
\text { Proposições aprovadas conclusivamente nas comissões na 52 }\end{array}$} & 407 & $100 \%$ \\
\hline 6egislatura & & \\
\hline 6.3 Recursos a Projetos de Lei com fundamentado no art. 132, § 2 & 49 & $12,03 \%$ \\
\hline 6.3.1 Recurso aprovado ao término da Legislatura & 2 & $0,49 \%$ \\
\hline 6.3.3 Recursos arquivados ao término da Legislatura & 22 & $5,40 \%$ \\
\hline
\end{tabular}

Os 2 recursos, aprovados em Plenário ao término da Legislatura, correspondem apenas a $0,49 \%$ do total de proposições aprovadas em comissões que, de fato, foram à análise do Plenário. Uma foi transformada em norma jurídica, mas tramitou em regime de urgência; a outra ainda encontra-se "em tramitação" no Senado Federal.

Dos 22 recursos que tramitavam ao término da Legislatura, correspondentes a 5,40\% do total citado, atualmente 20 deles ainda tramitam na Casa, sobrestando-se seus projetos. Temos que 1 sofreu prejudicialidade, e outro, retirada de assinaturas, com arquivamento. Portanto, em regra, essas proposições não lograram êxito. Como vimos, o projeto ao qual o recurso foi 
arquivado por requerimento continuou tramitando por urgência.

Quanto ao resultado das 29 proposições que tiveram os recursos arquivados (incluem-se aqui os 2 recursos aprovados no Plenário): 15 não lograram êxito (incluem-se neste grupo os "em tramitação", os arquivados, o prejudicado e os que sofreram veto presidencial total); 7 foram parcialmente sancionadas, e 7 proposições aprovadas conclusivamente nas comissões chegaram a ser sancionadas integralmente, conforme quadro abaixo.

Tabela 11 - Análise do êxito alcançado ao fim da tramitação legislativa pelos Projetos de Lei aos quais os respectivos recursos foram arquivados na $52^{\mathrm{a}}$ Legislatura na $\mathrm{CD}$

\begin{tabular}{l|c|c}
\hline & Quant. & $\%$ \\
\hline Proposições aprovadas conclusivamente nas comissões na 52 ${ }^{\text {a Legislatura }}$ & 407 & \\
\hline Das proposições que seguiram seu curso natural - recursos arquivados & 29 & $100 \%$ \\
\hline Não lograram êxito & 7 & $24 \%$ \\
\hline Veto Presidencial Total & 6 & $21 \%$ \\
\hline Sanção com Veto Parcial - mantido ou a ser apreciado & 7 & $24 \%$ \\
\hline Sanção "total” & 7 & $24 \%$ \\
\hline
\end{tabular}

Então, partindo-se da informação de que das 407 proposições aprovadas nas comissões na $52^{\mathrm{a}}$ Legislatura 49 receberam recursos, temos que, desses recursos, 29 já foram arquivados. E, dos arquivados, apenas 7 chegaram à sanção na íntegra, o que corresponde a dizer que apenas um quarto deles foram concluídos positivando-se a norma - $24 \%$ dos projetos.

Apresentamos, para melhor visualização, o esquema desta situação global dos recursos constitucionais às proposições já aprovadas em comissão:

Gráfico 9 - Análise do aproveitamento das proposições que receberam recurso constitucional contra o poder conclusivo das comissões na $52^{\mathrm{a}}$ Legislatura da CD

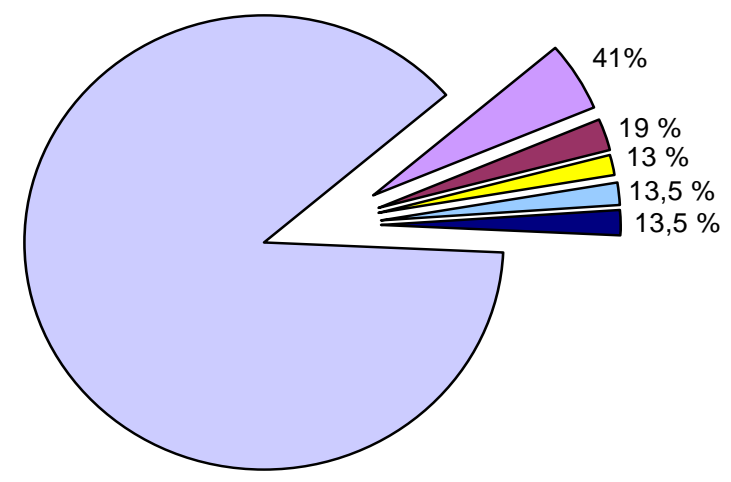

$\square 20$ proposições sobrestadas por recursos

$\square 9$ PLs tramitando ou arquivados

$\square 6$ proposições com Veto Presidencial Total

$\square 7$ proposições sancionadas com Veto Presidencial Parcial

7 proposições sancionadas "integralmente"

$\square 358$ PLs apreciados conclusivamente na CD sem interposição de recursos 
Do Gráfico 9 temos que apenas 13,5\% dos projetos de lei que sofreram recursos foram sancionados integralmente. Podemos também apresentar outras comparações em função das 20 proposições que, após arquivo dos recursos, chegaram à análise do Executivo: 6 - totalmente vetadas, 7 - parcialmente vetadas e 7 - sancionadas. Inclui-se entre as sancionadas aquela em que o recurso foi aprovado em Plenário, analisada no item 6.3.1.

Por conseqüência, somando-se aquelas proposições sobrestadas, em tramitação, arquivadas e as integralmente vetadas, temos 35 proposições "aprovadas conclusivamente nas comissões" na $52^{\mathrm{a}}$ Legislatura na Câmara dos Deputados que ainda hoje não lograram êxito, pois não foram positivadas.

Concluímos que praticamente três quartos dos recursos apresentados serão definitivamente arquivados. É lamentável que esses projetos já apreciados e aprovados pelas comissões temáticas na Câmara dos Deputados nem cheguem à apreciação executiva e, se chegam, são vetados na íntegra.

Por fim, temos que apenas um quarto das proposições que receberem o recurso constitucional contra o poder conclusivo na $52^{\mathrm{a}}$ Legislatura serão positivadas pelo menos em parte. Integralmente sancionadas: apenas 6 ocorrências. Isto corresponde a dizer que somente 1,47\% dessas proposições chegam ao ordenamento jurídico conforme elaboração legislativa.

\subsubsection{Análise dos primeiros signatários}

Raul Horta argumenta que as lideranças legislativas governamentais podem ser fortalecidas ou enfraquecidas pelos mecanismos constitucionais contemporâneos e vincula isto à quantidade de regras instrumentais a serviço presidencial. E conclui que a ampliação da competência do Executivo no processo legislativo é uma tendência nos mecanismos constitucionais contemporâneos (Horta, 1995, p.539).

Como se sabe, para a interposição desse recurso contra o poder conclusivo, proposição de iniciativa coletiva, é necessário que haja assinaturas de um décimo dos membros da Casa (art. 58, CF). Com o fim de encontrar as lideranças legislativas a serviço governamental, passamos a analisar os primeiros signatários, que encabeçam e emplacam esse pleito. Acreditamos que esta sua atuação na busca de apoiamento para essa proposição acessória é de fundamental importância para a existência.

O Regimento Interno da Câmara dos Deputados, art. 102, § 2º determina: "As atribuições ou prerrogativas regimentais conferidas ao Autor serão exercidas em Plenário por um só dos signatários da proposição, regulando-se a precedência segundo a ordem em que a subscreveram." Observando-se a lista de precedência, indiscutível está a importância desse primeiro signatário. 
Como fundamento, destacamos a decisão na Questão de Ordem nº 175/2007, levantada pelo Deputado Fernando Coruja (PPS-SC), que deu interpretação restrita ao proponente da iniciativa coletiva:

5. A definição de autoria é dada em sede regimental. A praxe da Casa tem consagrado uma interpretação restrita, de sorte que, para as proposições de autoria coletiva voluntária aplica-se o art. $102, \S 1^{\circ}$, considerando autores todos os subscritores, e para as proposições com subscrição de apoiamento exigida pela Constituição ou pelo Regimento aplica-se o art. $102, \S 2^{\circ}$, para considerar autor somente o primeiro signatário.

Entre os argumentos dessa decisão, encontramos o fato de que as assinaturas consignadas à proposição não vincula o parlamentar ao conteúdo da proposição, podendo, inclusive, opor-se a ele. E, muitas vezes, os parlamentares apenas motivados pela inspiração democrática assinam essas proposições, o que é entendido como parte da cortesia e convivência parlamentar.

Assim, consideramos e analisamos os primeiros signatários de todos os 49 recursos e seus partidos políticos, com o objetivo de buscar encontrar as lideranças políticas atuantes neste processo recursal contra a apreciação conclusiva das proposições já apreciadas favoravelmente nas comissões temáticas, e encontramos os seguintes dados:

Tabela 12 - Tabulação dos partidos dos $1^{\circ}$ s signatários aos recursos apresentados contra 0 poder conclusivo das comissões na $52^{\mathrm{a}}$ Legislatura da CD

\begin{tabular}{c|c|c|c|c|c|c}
\hline Sessão Legislativa & $\mathbf{2 0 0 3}$ & $\mathbf{2 0 0 4}$ & $\mathbf{2 0 0 5}$ & $\mathbf{2 0 0 6}$ & $\begin{array}{c}\text { Total na } \\
\text { Legislatura }\end{array}$ & Incidência \% \\
\hline Rec. Apresentados & 9 & 2 & 15 & 23 & 49 & $100 \%$ \\
\hline PC do B & 2 & 0 & 1 & 0 & 3 & 6,12 \\
\hline PFL & 1 & 0 & 2 & 2 & 5 & 10,20 \\
\hline PL & 0 & 0 & 0 & 1 & 1 & 2,04 \\
\hline PMDB & 1 & 1 & 2 & 2 & 6 & 12,24 \\
\hline PP & 0 & 0 & 2 & 1 & 3 & 6,12 \\
\hline PPS & 0 & 0 & 0 & 1 & 1 & 2,04 \\
\hline PSB & 1 & 0 & 0 & 0 & 1 & 2,04 \\
\hline PSDB & 0 & 0 & 0 & 5 & 5 & 10,20 \\
\hline PT & $\mathbf{0}$ & $\mathbf{1}$ & $\mathbf{7}$ & $\mathbf{9}$ & $\mathbf{1 7}$ & $\mathbf{3 4 , 7 0}$ \\
\hline PTB & 4 & 0 & 0 & 2 & 6 & 12,24 \\
\hline PV & 0 & 0 & 1 & 0 & 1 & 2,04 \\
\hline
\end{tabular}

Com essa tabulação, identificamos que o Partido dos Trabalhadores - PT, partido do governo, foi o responsável direto pela interposição de não menos que 17 proposições das 49 impetradas. Assim, percentualmente temos que o PT responde pela apresentação de 34,70\% dos recursos. Considerando-se apenas essa análise por partidos, obtivemos um resultado que, por si só, já é bem representativo.

Agora, objetivando encontrar a influência das lideranças legislativas governamentais, 
buscamos, junto à Liderança do Governo na Câmara dos Deputados, identificar os partidos de apoio à base do Executivo na Casa. Agrupando-se esses primeiros signatários de partidos que apoiam o governo, e separando os partidos independentes, obtemos o seguinte cenário:

Tabela 13 - Análise dos recursos constitucionais (art. 58, § 2, I, CF) separados por partidos da base do Governo em cada Sessão Legislativa na $52^{\mathrm{a}}$ Legislatura da CD

\begin{tabular}{|c|c|c|c|c|c|c|}
\hline Sessão Legislativa & 2003 & 2004 & 2005 & 2006 & $\begin{array}{c}\text { Total na } \\
52^{\mathrm{a}} \text { Legislatura }\end{array}$ & $\begin{array}{c}\text { Incidência } \\
\%\end{array}$ \\
\hline $\begin{array}{c}\text { Partidos } \\
\text { Da base do } \\
\text { Governo (*) }\end{array}$ & $\begin{array}{c}\text { PC do B, PDT, } \\
\text { PL, PMDB, } \\
\text { PMN, PP, PPS, } \\
\text { PRONA, PSB, } \\
\text { PSC, PT, PTB e } \\
\text { PV. }\end{array}$ & $\begin{array}{c}\text { PC do B, } \\
\text { PDT, } \\
\text { PL, PMDB, } \\
\text { PPS, PSB, } \\
\text { PSC, PT, } \\
\text { PTB e PV. }\end{array}$ & $\begin{array}{l}\text { PC do B, PDT, } \\
\text { PL, PMDB, } \\
\text { PMR, PP, } \\
\text { PRONA, PSB, } \\
\text { PSC, PT, PTB, } \\
\text { PTC e PV. }\end{array}$ & $\begin{array}{l}\text { PC do B, PDT, } \\
\text { PL, PMDB, PP, } \\
\text { PSB, PSC, PT, } \\
\text { PTB e PV. }\end{array}$ & 49 & $100 \%$ \\
\hline $\begin{array}{l}\text { Recursos com primeiros } \\
\text { signatários de partidos da } \\
\text { base do Governo }\end{array}$ & 8 & 2 & 13 & 15 & 38 & $77,55 \%$ \\
\hline $\begin{array}{l}\text { Recursos com primeiros } \\
\text { signatários de partidos } \\
\text { fora da base do governo }\end{array}$ & 1 & 0 & 2 & 8 & 11 & $22,45 \%$ \\
\hline
\end{tabular}

(*) A informação dos partidos que compõem a base do Governo foi fornecida pela Liderança do Governo na Câmara dos Deputados, em 10 em novembro de 2009.

A Tabela 13 apresenta dados reveladores que demonstram a participação dominante de parlamentares vinculados à base do governo na interposição desses recursos ao poder conclusivo que, em regra, neutralizaram proposições já prontas para positivação.

Podemos ilustrar graficamente as duas situações apresentadas: incidência do partido da situação - Gráfico 10 - e incidência de deputados da base do Governo - Gráfico 11 - como primeiros signatários de recursos contra o poder conclusivo das comissões. Vejamos:

\section{Gráfico 10 - Incidência do partido da situação - Partido dos Trabalhadores - PT - como $1^{\circ} \mathrm{s}$ signatários dos recursos contra o poder conclusivo das comissões \\ na $52^{\text {a }}$ Legislatura da CD}

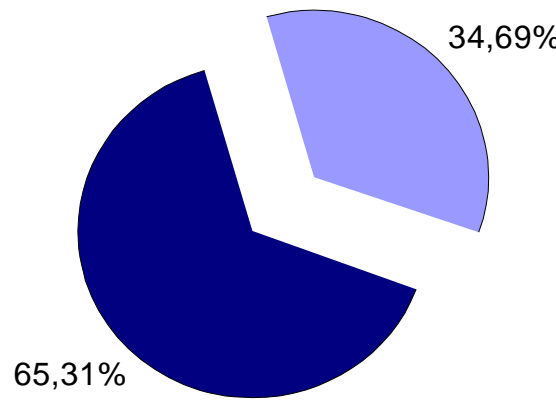

$\square 17$ recursos com $1^{\circ}$ s signatários do Partido dos Trabalhadores - PT - partido do governo

32 recursos com $1^{\circ}$ s signatários dos 11 partidos na Casa que impetraram recursos (PC do B, PFL, PL, PMDB, PP, PPS, PSB, PSDB, PT, PTB e PV)

Por esse mapeamento dos primeiros signatários dos recursos encontramos que o PT, partido do Governo, individualmente, é o responsável pela interposição de 17 recursos, o que corresponde a $34,70 \%$ dos encabeçados por parlamentares do partido da situação. 
Quanto à análise da base do Governo, temos:

Gráfico 11 - Análise da incidência de deputados da base do Governo como $1^{\circ}$ signatários dos recursos contra o poder conclusivo das comissões na $52^{\mathrm{a}}$ Legislatura da CD

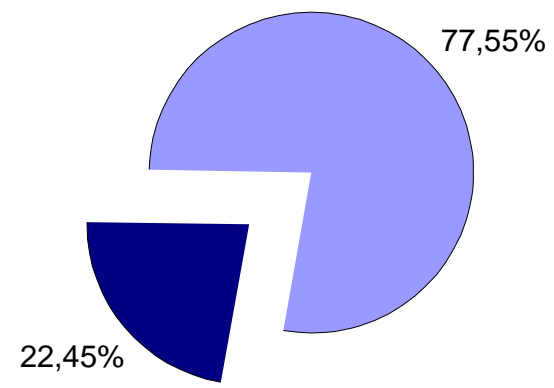

$\square 38$ recursos com $1^{\circ} \mathrm{s}$ signatários da base do Governo

- 11 recursos com $1^{\circ} \mathrm{s}$ signatários de outros partidos

Ao identificarmos os partidos da base do governo agrupando os primeiros signatários, conforme Gráfico 11, temos 38 recursos encabeçados por parlamentares governistas. Partindo do total de 49 recursos do gênero apresentados nesta 52 $2^{\mathrm{a}}$ Legislatura, restam apenas 11 deles, que foram encabeçados por parlamentares fora da base do Executivo na Câmara dos Deputados.

\section{Estudo sobre a interferência do Executivo sobre o recurso constitucional}

Os problemas relativos às diversas influências que modificam a tramitação legislativa dos projetos de lei conclusivos, com foco na análise do recurso constitucional do art. 58 contra o poder conclusivo das Comissões, assim como o estudo da interferência do Executivo sobre ele são os desafios deste trabalho.

Sabemos que esse dispositivo constitucional que assegura o poder pleno das comissões, salvo recurso, tem por intenção o fortalecimento do Poder Legislativo e a valorização dos trabalhos de comissão. É uma ferramenta de especialidade das comissões e agilidade dos trabalhos legislativos. O recurso se apresenta como uma alternativa aos parlamentares para levar o projeto de lei já aprovado em comissões à discussão plenária.

Identificar as razões que levaram os parlamentares na $52^{\mathrm{a}}$ Legislatura na Câmara dos Deputados a alterar a tramitação das proposições com poder pleno das comissões vem sendo o nosso desafio. Assim, na pesquisa analisamos o recurso constitucional separadamente dos 07 recursos a PDCs conclusivos, porque incidem sobre matérias diversas e tem por fundamento regimental o Parecer Normativo $n^{\circ}$ 09/90 da CCJR.

Observamos entre os projetos de lei diversas justificativas para a motivação dos recursos pelos parlamentares. E destacamos as duas principais razões de existência: 35 recursos pretenderam dar sobrevida a projetos "fracassados" sujeitos ao arquivamento, interpostos pelo art. 133 do RICD; e 49 recursos solicitaram nova análise em Plenário aos projetos de lei já 
aprovados em comissão, baseados no art. 132, § $2^{\circ}$ do RICD. Neste último caso, do total de 407

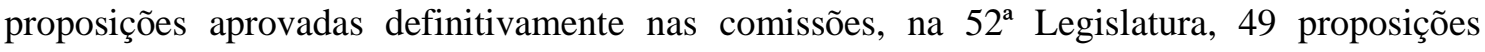
receberam o clássico recurso contra o poder conclusivo das comissões.

Nesta $52^{\text {a }}$ Legislatura, dos 49 recursos apresentados apenas 2 foram aprovados em Plenário. A maioria dos recursos apresentados estão fadados a se eternizarem "em tramitação". A aprovação dos dois acima citados ocorreu no clamor dos líderes governistas ou após grande espera para apreciação. Assim, a interposição desse instituto implica colocar seus projetos na categoria dos "arquivados vivos".

Destacamos que de 20 projetos 4 foram à análise do Executivo e apenas 7 proposições chegaram à sanção integralmente conforme legisladas. Descontando-se duas que sofreram "urgência" de líderes, sobram 5 que tiveram seus recursos arquivados e foram sancionadas integralmente. Por fim, só houve anuência apenas a $25 \%$ do que foi submetido ao Presidente da República pelo Legislativo.

É importante destacar que, quando medidas provisórias sobrestão a pauta do Plenário da Câmara dos Deputados, já há interferência do Executivo na pauta do Legislativo, pois têm preferência de votação. $\mathrm{O}$ fato também prejudica a possível apreciação dos recursos conclusivos no Plenário, que, em regra, não são nem pautados.

Neste contexto, a pesquisa conclui por dados que comprovam que três quartos dos recursos em tramitação não permitem que os respectivos projetos cheguem à sanção. Em regra, as proposições apenas concluem suas tramitações quando os respectivos recursos são arquivados: por ausências ou retirada de assinaturas. Não sendo isto, se pautadas, sua apreciação em Plenário, em regra, será sempre preterida por outras matérias legislativas e pela apreciação das medidas provisórias.

Sobre o tema sobrestamento da pauta, destacamos os estudos de Vieira:

O sobrestamento da pauta do Plenário da Câmara dos Deputados por Medidas Provisórias tem significado, portanto, um represamento do fluxo de tramitação das matérias sujeitas a sua deliberação, tornando ineficazes até mesmo recursos regimentais rotineiros de definição de prioridades de deliberação, como os requerimentos de urgência regimental, e se constituindo em elemento novo nos procedimentos de acordo de liderança com vista ao estabelecimento da agenda de votação (Vieira, 2005, p.40).

Esse represamento, também aos recursos ora analisados, demonstra uma grande concentração do poder de influência do Executivo sobre as ações do Poder Legislativo. O resultado que apuramos corrobora esse entendimento.

Necessário se faz criar mecanismos legislativos, como prazos regimentais para apreciação desses recursos, para só assim serem apreciados e não haver prejuízo aos trabalhos legislativos. Atualmente, eles simplesmente sobrecarregam a lista dos "prontos para a pauta". 


\subsection{A representatividade da base do Governo na interposição do recurso}

Mapeamos os partidos políticos dos primeiros signatários de cada recurso para buscar demonstrar a influência do Executivo na paralisação dos projetos já apreciados conclusivamente.

Agrupamos os primeiros signatários, inicialmente por partido, e apuramos que o PT, o partido do Governo, individualmente, é o bloco de parlamentares responsável pelo maior número de interposições. Também estudando a base de apoio ao Governo na Câmara dos Deputados encontramos dados reveladores.

Nesta $52^{\mathrm{a}}$ Legislatura, quanto aos recursos há uma presença forte da liderança legislativa governamental, pois a presença dos partidos aliados como primeiros signatários está comprovada em $74,55 \%$ dos recursos do gênero. $O$ fato não pode ser desconsiderado. Portanto, existe participação maciça de parlamentares vinculados ao projeto do Executivo, no sobrestamento dos trabalhos legislativos, especialmente, pela interposição de recursos que raramente são apreciados.

Pela alta incidência desses parlamentares governistas encabeçando os recursos ao Plenário contra proposições já aprovadas conclusivamente nas Comissões da Casa, não resta dúvidas quanto à influência do Executivo na produção desses recursos e, consequentemente, na neutralização dos respectivos projetos de lei já aprovados em comissões.

$\mathrm{Na}$ medida que os agentes do governo no Parlamento se mobilizam para garantir a política governamental, o Presidente da República não necessita manifestar-se, ou orquestrar ações, apenas se beneficia delas.

Com essa descoberta, reforçamos o argumento de Raul Machado Horta que, em sua obra Estudos de Direito Constitucional, aponta: "O Direito Constitucional do Estado que planeja a ação econômica modelou à sua semelhança o processo legislativo. A iniciativa governamental passou a comandar a atividade legislativa e o legislador moderno alterou as regras tradicionais de sua conduta legislativa" (Horta, 1995, p.530)

O Executivo procura impor ao Congresso Nacional suas prioridades. Como é sabido, o Parlamento fica a sua mercê quando há medidas provisórias na pauta legislativa. Essa interferência no processo legislativo também pode ser identificada em ingerências menores do Executivo, como nos casos em que influencia a base do governo a interpor proposições, como o recurso contra o poder conclusivo.

\subsection{Análise da inclusão dos recursos na pauta do Plenário na Câmara dos Deputados}

Como vimos na análise de dados, os recursos, segundo andamento legislativo, após publicados estão prontos para a inclusão na pauta do Plenário.

Buscando perseguir a influência do Executivo na pauta do Plenário na Câmara dos 
Deputados, iniciamos por destacar os presidentes no período da $52^{\mathrm{a}}$ Legislatura. Presidiu a Casa entre 2003-2004 o Deputado João Paulo Cunha (PT/SP). Em 2005, o Deputado Severino Cavalcante (PP/PE) esteve à frente dos trabalhos do início de fevereiro a 21 de setembro. Após sua renúncia, assumiu o cargo o Deputado Aldo Rebelo ( $\mathrm{PC}$ do B/SP), que completou este mandato até janeiro de 2007.

Os presidentes da Câmara dos Deputados supracitados, à época de seus mandatos, pertenciam aos partidos PT, PP e PC do B. Estavam, portanto, vinculados a agremiações que participavam da base de apoio ao governo.

$\mathrm{O}$ fato de os recursos na $52^{\mathrm{a}}$ Legislatura serem, em regra, publicados e dificilmente pautados, aponta para uma suspeita de que há influência do Executivo na pauta da Casa. Apuramos que, dos 21 recursos tramitando "prontos para pauta", apenas 2 constam como "matéria sobre a Mesa". E, ainda assim, mesmo quando pautados, sistematicamente, foram sobrestados por outras matérias e pela apreciação de medidas provisórias oriundas do Executivo.

Nessa fase, ainda não foi aberta oportunidade de manifestação do Executivo, portanto, não podemos responsabilizá-lo diretamente de manobras. Porém, a presença de Presidentes da Casa da base do governo e a não inclusão dos recursos na pauta de votação, por si só, já demonstram uma oscilação do processo. O sobrestamento da pauta legislativa por medidas provisórias é um problema que o parlamento vem enfrentando. Veremos a solução paliativa da urgência, usada quando há real interesse político na apreciação plenária.

\subsection{As "urgências" requeridas a Projetos de Lei com Recurso}

Nos casos de projetos de lei em que o Presidente da República tem interesse para seus planos de governo, há mecanismos de interferência legislativa mais ágil e eficiente, respaldados pela Constituição.

Na parte teórica deste trabalho, apresentamos a urgência como forma de perda do poder pleno das comissões, que pode ser requerida ao longo de toda a tramitação em comissões. Como este regime tramita em prioridade de apreciação, supõe-se maior agilidade nos trabalhos.

No recurso constitucional do art. 58 há o poder de protelar a edição de "leis" já elaboradas. Mas suspeitamos que o poder de agenda do Executivo nas atividades do Legislativo esteja mais próximo das solicitações de "urgências" e na edição numerosa de medidas provisórias, pois quando há interesse na apreciação e votação das matérias em Plenário, a "urgência" é o instrumento jurídico utilizado.

Consta dos registros da Coordenação de Comissões Permanentes da Câmara dos Deputados que o Executivo, diretamente por mensagem fundada na urgência constitucional do

\footnotetext{
${ }^{4}$ Note-se que os recursos apreciados e aprovados no plenário também constaram na pauta.
} 
art. 64, globalmente já levou à apreciação plenária 16 proposições - originariamente conclusivas. Além desta "urgência", o governo também se beneficia da ação de líderes governistas que, na Câmara dos Deputados, têm a prerrogativa de solicitar a "urgência urgentíssima”, fundada no art. 155 do RICD.

O primeiro recurso aprovado em plenário nesta $2^{\mathrm{a}}$ Legislatura foi o REC 25/2006 ao PL n $73 / 1999$. Encerrou sua tramitação na Câmara dos Deputados sob "urgência" e ainda aguarda apreciação no Senado Federal. Entre os projetos que receberam recursos estudados neste trabalho e que finalmente foram sancionados ${ }^{5}$, destacamos quatro que, mesmo sobrestados pela interposição do recurso, receberam solicitação de "urgência". Esses quatro projetos de lei conclusivos, remetidas ao Executivo, além de receberem o recurso contra a apreciação plena das comissões, tramitaram por "urgência". E esses requerimentos de "urgência" têm por primeiros signatários os seguintes líderes: PL n ${ }^{\circ}$ 2550/2003 - Deputado Hugo Leal (Líder do PSC), PL n ${ }^{\circ}$ 5.318/2005 - Deputado Miro Teixeira (Líder do PDT), PL no 5.845/2005 - Deputado Miro Teixeira (Líder do PDT), e PL nº 6.467/2005 - Deputado Arlindo Chinaglia (Líder do PT).

Considerando-se apenas os líderes que encabeçam os requerimentos, temos que todos eles são representantes de bancadas de apoio ao governo. Portanto, atuam em consonância com o projeto da situação política vigente. Isso demonstra que quando há real interesse do Executivo, os próprios líderes da base de apoio ao Governo na Casa legislativa se mobilizam para resgatar essas proposições deste sobrestamento recursal, levando-as à apreciação do Plenário. E, dessa forma, o Executivo, na figura do Presidente da República, não necessita manifestar-se.

Ora, se há interesse do Executivo em votação de proposições originariamente com poder conclusivo, um pedido de "urgência" do art. 64, da CF, também seria o suficiente para que uma proposição fosse apreciada em Plenário, devido aos poderes delegados na Carta Magna ao Presidente da República, especialmente pela Emenda Constitucional n 32, de 2001.

A eficiência da "urgência" é incontestável. Nestes quatro casos em que as proposições tramitaram nesse regime, todas concluíram sua tramitação de forma positiva pela sanção com ou sem veto: Lei $\mathrm{n}^{\circ} 11.383 / 2006$ e Lei $\mathrm{n}^{\circ} 11.493 / 2007$, sancionadas integralmente, Lei $\mathrm{n}^{\circ}$ 11.416/2006, com veto presidencial parcial - mantido, e Lei $\mathrm{n}^{\mathrm{o}} 11.877 / 2008$ com veto presidencial parcial a ser apreciado. Portanto, nesses casos, houve a positivação das proposições, mesmo que com veto parcial.

O Executivo se beneficia do apoio de líderes da base governista que têm a prerrogativa de solicitar essas "urgências urgentíssimas", nos termos do art. 155 do RICD. Mas, se desapercebidamente, uma matéria é aprovada conclusivamente nas comissões sem que haja interesse executivo na sua positivação, o melhor caminho é o recurso do art. 58, da

\footnotetext{
${ }^{5}$ Leis nos $11.383 / 2006,11.416 / 2006,11.493 / 2007$ e $11.877 / 008$. 
Constituição, pois, nesses casos, a proposição será "adormecida". O Executivo, por sua vez, não se exporá ao veto.

Resumidamente, se o Executivo tem interesse na matéria, pede-se "urgência" e a aprecia em Plenário. Se não há interesse e mesmo assim o projeto chega a ser aprovado em todas as comissões, o Executivo pode se posicionar em três caminhos: influenciar o Legislativo, por meio de suas lideranças para a promoção do recurso constitucional que sobrestará a proposição por tempo indeterminado, ou, quando receber a proposição por remessa do Legislativo, exercer seu poder de veto, total ou parcial.

\subsection{Análise das proposições remetidas ao Executivo, após o arquivamento dos seus recursos}

A análise das proposições remetidas ao Executivo é de fundamental importância para este estudo, porque após esta apreciação executiva é que se conclui o ciclo da produção legislativa.

Dessa forma, a proposição principal, após o arquivo do recurso, segue ao Plenário - se o recurso foi provido, ou à sanção, ou ao Senado Federal - nos demais casos. Assim, para a análise dos resultados, agrupamos os seguintes recursos arquivados: devolvidos ou arquivados por não conter número mínimo, arquivados por retirada de assinaturas, os recursos não apreciados por aprovação de "urgência" ao projeto de lei, os prejudicados e, ainda, os aprovados em Plenário. O Executivo se manifestará por sanção ou veto. Alexandre de Moraes assegura que sanção é ato integrativo formal de sacramento do ato legislativo, é aquiescência do Presidente; e o veto é a manifestação da discordância do Presidente ao projeto de lei, estando, portanto, consagrado o exercício do poder político no controle da elaboração de normas jurídicas. (Moraes, 2006, p. 614-617)

Considerando a cooperação legislativa aos interesses sociais e governamentais, o veto deve ser pouco utilizado. Portanto, analisando-se pela ótica do Executivo, é mais conveniente que essas proposições, que estão em desacordo com os "planos de governo", não sejam remetidas à sanção. Para que não seja necessário utilizar-se do veto, é preferível ao Executivo que elas fiquem eternamente "em tramitação" no Legislativo.

Porém, nesses casos em que há interposição do recurso a proposições já conclusivamente apreciadas, observamos que a incidência de veto ocorre em 68,42\% das proposições remetidas ao Executivo. Apenas o fato de terem recebido recurso já demonstra que tratar-se de projetos "polêmicos", já que suas aprovações nas comissões não foram suficientemente capazes de unificar nem mesmo o entendimento na Casa Legislativa. Assim, os parlamentares optam pelo recurso ao Plenário, lembrando que a maioria deles é encabeçada por deputados da base de apoio ao governo. 
Esta questão do veto é um ponto muito importante para a nossa reflexão. Os 29 recursos arquivados, salvo o prejudicado, liberaram os projetos de lei para seguirem seu curso de tramitação. Desses, 9 projetos ainda estão em tramitação ou arquivados. Destacamos apenas as 20 proposições enviadas à sanção presidencial por arquivamento dos recursos. Distribuídas graficamente temos:

Gráfico 12 - Análise da ação do Executivo às proposições remetidas à sanção após arquivo dos recursos constitucionais (art.58, $\$ 2^{\circ}$, I, da CF) na $52^{\mathrm{a}}$ Legislatura da CD

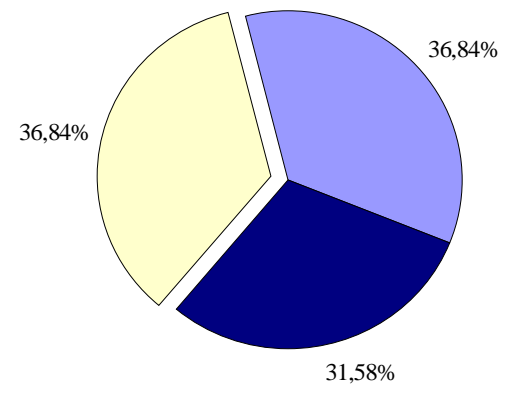

$\square 7$ proposições sancionadas "integralmente"

$\square 7$ proposições sancionadas com Veto Presidencial Parcial

- 6 proposições com Veto Presidencial Total

Obs. Está inclusa a Lei no 11.493/2007, com sanção integral, a qual o REC. nº 257/2006 aprovado em Plenário, foi também arquivado.

Essa manifestação do Presidente da República quanto à produção legislativa detalhada no Gráfico 12 demonstra a preferência presidencial pelo veto. O Executivo enviou mensagem de veto total a 6 proposições, cujos recursos foram arquivados.

Das 49 proposições que sofreram recurso, apenas 20 chegaram à remessa do Executivo. Daquelas, 29 projetos que receberam recursos não chegaram ao Executivo, correspondem a $59,18 \%$. Se a essas 29 proposições incluirmos os 13 projetos que receberam veto, temos que as 42 proposições já aprovadas conclusivamente nas comissões, representando 85,71\% do total, perderam sua integralidade de mérito, caracterizando-se assim o "Poder Negativo de Veto" do recurso constitucional, art. $58, \S 2^{\circ}, \mathrm{I}$.

Estudando as motivações que fundamentam os recursos ao Plenário, observamos a maior incidência dos argumentos: abrangência e relevância da proposição e inconformismo pela aprovação do mérito. A grande maioria dos recursos está sem fundamentação ou fundada em argumentos genéricos. Isto porque o comando constitucional condiciona apenas o número de parlamentares para apresentação do recurso e não trata das motivações.

Esse recurso, via de regra, paralisa a matéria, e ainda pode favorecer o Presidente da República se, ele, nestes casos, pretender manifestar-se pelo veto. Sem ônus político beneficiase do poder negativo de veto do recurso. 


\subsection{Considerações finais}

Após as prerrogativas asseguradas ao Presidente da República com o advento da Emenda Constitucional no 32/2001, há constante edição de medidas provisórias. Os recursos constitucionais que estão "prontos para pauta" não conseguem prosperar, pois raramente chegam a estar "sobre a Mesa" com prioridade.

A aprovação deles, proposições acessórias, em Plenário, na 52ª Legislatura ocorreu apenas em duas situações. Em uma delas está claro o objetivo de desobstruir-se o projeto de lei, principal, para, enfim, tramitar em regime de urgência. O segundo recurso permaneceu por 10 vezes "sobre a Mesa", sendo sobrestado pela Medida Provisória n 275/2005, para então ser aprovado.

Com esses dados apurados, temos que a utilidade desse recurso para o Executivo é apenas a paralisação de projetos inconvenientes ao seu programa de governo. Nesse contexto, ele pode, exercendo sua influência sobre a bancada de apoio ao governo na Casa legislativa, patrocinar a sua interposição, sem o desgaste com o excesso de vetos.

Politicamente, a não utilização dessa capacidade de veto preserva o Legislativo. Observa-se que, apesar da mobilização dos parlamentares em retirar as assinaturas para que as proposições tramitassem, o destino delas, nesses casos, foi o veto total.

Para combater a paralisação aos projetos ocasionada pelos recursos, os parlamentares têm a prerrogativa de, ao se mobilizarem, retirar os recursos de tramitação e dar andamento às proposições. Cabe ao Executivo sancionar ou vetar esses projetos. De toda forma, apuramos que desses projetos que chegam à sanção, cerca de $70 \%$ sofrem algum veto: parcial ou total. Estamos diante de um dilema: o poder negativo de veto do recurso constitucional, que veta o que nunca finda de tramitar, ou o veto constitucional assegurado ao Executivo.

Essa capacidade de exercer "veto" parcial ou integral sobre as matérias já aprovadas no Congresso Nacional permite ao Executivo interferir diretamente na competência de produção legislativa do Parlamento. O poder negativo de veto do recurso constitucional trabalha a favor dos interesses do Governo, porque com o sobrestamento dessas proposições o governo não necessita se manifestar, não se desgasta com o Legislativo, nem se revela à sociedade.

E o pior: o Legislativo ainda tem que apreciar o veto. A sua análise deve obedecer ao trâmite do art. 66 da Constituição. Apenas por maioria absoluta dos Deputados e Senadores o veto poderá ser rejeitado. Raramente tal prerrogativa, "derrubada do veto", é utilizada no Parlamento. Tanto por se tratar de apreciação sujeita a quórum especial, como por configurar um confronto com a palavra do Presidente da República, o Legislativo vem confirmando essa ação executiva.

Essa tramitação legislativa do projeto com recurso não é muito diferente dos demais, mas é mais demorada, ineficiente e cíclica: aprecia-se o projeto, aprecia-se o recurso, retira-se o 
recurso ou aprecia-se o projeto em Plenário, envia-se à revisão ou à sanção, é vetado, aprecia-se o veto, enfim. Proposições apreciadas legitimamente no processo legislativo, prontas, não são positivadas e permanecem "tramitando", ficam fora do ordenamento jurídico ou são vetadas. Isso demonstra que há regras procedimentais no trâmite legislativo dificultando a produção da norma, facilitando a interferência da ação direta do Executivo na formação da lei ou, simplesmente, trabalhando a favor dos interesses do Governo.

Apontamos, por oportuno, que ficaram prejudicadas as indagações sobre se a posição dominante das comissões desses projetos conclusivos prevalece quando da análise pelo Plenário. Isto porque fatores outros ocorreram com as duas únicas proposições sujeitas ao recurso e que foram apreciadas em Plenário: uma foi apreciada em Plenário sob outro

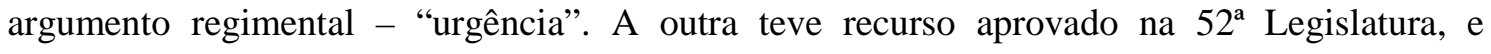
apreciação plenária na $53^{\mathrm{a}}$ Legislatura, também tramitou sob "urgência" na Câmara dos Deputados. Portanto, não há recurso aprovado que, por esta razão, tenha levado o projeto de lei ao plenário e produzido norma jurídica. Assim, a análise de mérito Comissão/Plenário e a posição dominante ficou prejudicada.

\section{Conclusão}

O "Poder Conclusivo das Comissões Permanentes" é de suma importância para o fortalecimento do processo legislativo. A valorização do trabalho das comissões especialistas fortalece, valoriza e aprimora a produção de normas jurídicas, que podem ser detalhadamente debatidas em fóruns temáticos próprios.

Essa hipótese de delegação legislativa interna para análise conclusiva das comissões objetiva tratar de questões de interesse social de forma especializada no trabalho parlamentar. Portanto, é importante conhecer as razões dos recursos constitucionais que invertem a lógica da tramitação conclusiva.

Ao longo deste trabalho, observamos que os procedimentos vêm sendo aperfeiçoados gradualmente. Porém, ainda há muito a se fazer. Entre as necessidades de melhoria, destacamos a uniformização das nomenclaturas e a unificação das matérias objeto das apreciações conclusivas das comissões temáticas das duas Casas Legislativas, Câmara dos Deputados e Senado Federal, como forma de facilitar o trabalho dos operadores e o trâmite legislativo.

Também é de fundamental importância, entre outras modificações, que a apreciação desses processos plenos de poder nas comissões seja diferenciada, destacando-se os projetos conclusivos das demais proposições para que recebam o tratamento e a avaliação especial que merecem, já que nessa apreciação, em regra, a decisão será definitiva, salvo recurso.

Os processos no parlamento tramitam por força da vontade política. Quanto aos recursos, para que cumpram sua função legislativa, é necessário que se atualize o regimento, 
estabelecendo-se prazos para sua apreciação plenária, o que não garante sua apreciação, mas sinaliza aos parlamentares uma necessidade de organização e método. É necessário controle legislativo, indexando-se esses recursos separadamente, também como forma de melhor visualizar e acompanhar o andamento dessas proposições. Já os recursos fundados no art. 133 devem ser apartados, pois se propõem a um fim específico.

Nesse contexto, a devida divulgação dos trabalhos de comissão junto à sociedade, legítima possuidora do direito a uma produção legislativa representativa, é essencial para que o recurso constitucional não seja manipulado. E com essa consciência, que os parlamentares sejam capazes de se organizar para retirá-los, remetendo os projetos de lei já aprovados ao Executivo que, não aquiescendo, manifeste-se. Isso fortalecerá as comissões especialistas e dará mais credibilidade ao Legislativo.

Não há dúvida, porém, de que o processo de aperfeiçoamento da tramitação legislativa caminha a passos largos.

\section{Referências}

BRASIL. Congresso. Câmara dos Deputados. Diário da Assembleia Nacional Constituinte. 18 mar 1988. p. 8620 a 8624.

BRASIL. Congresso. Câmara dos Deputados. Diário da Assembleia Nacional Constituinte (Atas de comissões).p. 114 a 115.

BRASIL. Congresso. Câmara dos Deputados. Diário da Assembleia Nacional Constituinte (Atas de comissões). p.151 a 156.

BRASIL. Congresso. Câmara dos Deputados. Diário da Assembleia Nacional Constituinte (Suplemento). 8 ago 1987. p. 31 a 32.

BRASIL. Congresso. Câmara dos Deputados. Diário da Assembleia Nacional Constituinte (Suplemento). 8 ago 1987. p. 70 a 71.

BRASIL. Congresso. Câmara dos Deputados. Diário da Assembleia Nacional Constituinte. Secretaria Geral da Mesa. Emendas Individuais. Emenda: 2P00107-6. (documento)

BRASIL. Congresso. Câmara dos Deputados. Diário da Assembleia Nacional Constituinte. CEDI/CELEG/SEDOP. Emenda Substitutiva. Emenda:2P02040-2. (documento)

BRASIL. Congresso. Câmara dos Deputados. Diário da Câmara dos Deputados. 13 dez. 2006, pág. 55009-55010

BRASIL. Congresso. Câmara dos Deputados. Fluxograma de apreciação conclusiva de projeto de lei. Disponível em <http://intranet.camara.gov.br/internet/processo legislativo/fluxo/plTramitacao/plConclusiva/index.html>. Acesso em: 28.08.2009. 1 p.

BRASIL. Congresso. Câmara dos Deputados. Fichas de tramitação. Disponível em <http://internet.camara.gov.br> Acesso em: ago. e out. de 2009.

BRASIL. Congresso. Câmara dos Deputados. Liderança do Governo. Relação de partidos da base do Governo. 2003. 2004. 2005. 2006. (documento)

BRASIL. Congresso. Câmara dos Deputados. Questão de Ordem. no 175/2007. Disponível em: <http://www2.camara.gov.br/plenario/qordem>. Acesso em 12 nov. 2009. 
BRASIL. Congresso. Câmara dos Deputados. Regimento Interno da Câmara dos Deputados: aprovado pela Resolução n.17, de 1989. $7^{\text {a }}$ ed. Brasília: Câmara dos Deputados, Coordenação de Publicações, 2006. 395 p.

BRASIL. Congresso. Senado Federal. Regimento Interno do Senado Federal: aprovado pela Resolução n. 93, de 1970. 2. v. - Brasília: Senado Federal, 2007. p. 310 e p. 427.

BRASIL. Constituição (1988). Constituição da República Federativa do Brasil. $26^{a}$ ed. Brasília: Câmara dos Deputados, Coordenação de Publicações, 2008. 464 p.

BRASIL. Supremo Tribunal Federal. Ação Direta de Inconstitucionalidade n ${ }^{\circ}$ 652-5, Maranhão. Ofensa ao art. 18, $\S 4^{\circ}$ da Constituição Federal. Princípio da reserva de Plenário. Medida liminar deferida em parte. Acórdão. Disponível em: <http://www.stj.gov.br〉. Acesso em: 08 out 2009.

FIGUEIREDO, Argelina; LIMONGI, Fernando. Mudança Constitucional, Desempenho do Legislativo e Consolidação Institucional. Revista Brasileira de Ciências Sociais, n.29, ano 10, p.175-201, out. 1995.

GUIMARÃES, Deoleciano Torieri (Org.). Dicionário Técnico Jurídico - 5. ed. rev. e atual. São Paulo: Rideel, 2003.

HORTA, Raul. Estudos de Direito Constitucional. Belo Horizonte: Livraria Del Rey Editora, 1995.

HORTA, Raul. O Processo Legislativo nas Constituições Federais Brasileiras. Revista de Informação Legislativa. Senado Federal: n. 101, ano 26, p.5-28, jan./mar.1989.

MORAES, Alexandre de. Direito Constitucional. - 20 ed. - São Paulo: Atlas, 2006. 972 p.

PACHECO, Luciana. A tramitação de proposições na Câmara dos Deputados: do início à fase das comissões. Brasília: Associação dos Consultores Legislativos e de Orçamento e Fiscalização Financeira. 2002. 120 p.

PACHECO, Luciana Botelho. O poder conclusivo das comissões da Câmara dos Deputados: uma alternativa viável para a apreciação dos projetos de iniciativa parlamentar. [manuscrito]. Universidade de Brasília. 2005. 53 p.

PEREIRA, Carlos e MÜLLER, Bernardo. Uma teoria de preponderância do Poder Executivo. O Sistema de Comissões no Legislativo Brasileiro. Revista Brasileira de Ciências Sociais, v. 15, n.43, p.45-67. jun. 2000.

SANTOS, Fabiano. A Reforma do Poder Legislativo. Revista Plenarium, Câmara dos Deputados, n. 1, p. 26-40, 2004.

VIEIRA, Fernando. O poder de apreciação conclusiva das comissões na Câmara dos Deputados: uma avaliação. Monografia apresentada como parte dos requisitos para a conclusão do curso de pós graduação Especialização em Gestão Legislativa da universidade de Brasília. Brasília. 2005. 89 p.

Artigo recebido em: 31/03/2010

Artigo aceito para publicação em: 27/04/2010 